\title{
Lightweight Self-consolidating Concrete with Expanded Shale Aggregates: Modelling and Optimization
}

\author{
Abdurrahmaan Lotfy ${ }^{1)}$, Khandaker M. A. Hossain ${ }^{2), *}$, and Mohamed Lachemi ${ }^{2)}$
}

(Received March 5, 2014, Accepted January 5, 2015, Published online February 13, 2015)

\begin{abstract}
This paper presents statistical models developed to study the influence of key mix design parameters on the properties of lightweight self-consolidating concrete (LWSCC) with expanded shale (ESH) aggregates. Twenty LWSCC mixtures are designed and tested, where responses (properties) are evaluated to analyze influence of mix design parameters and develop the models. Such responses included slump flow diameter, V-funnel flow time, J-ring flow diameter, J-ring height difference, L-box ratio, filling capacity, sieve segregation, unit weight and compressive strength. The developed models are valid for mixes with $0.30-0.40$ water-to-binder ratio, high range water reducing admixture of $0.3-1.2 \%$ (by total content of binder) and total binder content of $410-550 \mathrm{~kg} / \mathrm{m}^{3}$. The models are able to identify the influential mix design parameters and their interactions which can be useful to reduce the test protocol needed for proportioning of LWSCCs. Three industrial class ESH-LWSCC mixtures are developed using statistical models and their performance is validated through test results with good agreement. The developed ESH-LWSCC mixtures are able to satisfy the European EFNARC criteria for self-consolidating concrete.
\end{abstract}

Keywords: expanded shale aggregates, lightweight self-consolidating concrete, multi-objective optimization, water to binder ratio, high range water reducing admixture, total binder content, statistical model.

\section{Introduction}

Lightweight self-consolidating concrete (LWSCC) is expected to provide high workability without segregation and high durability with reduced weight. The success to production of high quality LWSCC lies in the use of aggregates. Expanded shale (ESH) is a ceramic material produced by expanding and vitrifying select shale's, in a rotary kiln. The process produces a high quality ceramic aggregate that is non-toxic, absorptive, dimensionally stable, structurally strong, durable, environmentally inert and light in weight. The use of expanded shale aggregate with other quality supplementary cementing materials (such as fly ash and silica fume) can provide highly workable and durable LWSCCs. ESH and other lightweight aggregates such as: clayey diatomite, pumice, slate, perlite, bottom ash etc. have been successfully used in the production of lightweight concretes (LWCs) over the decades (Stamatakis et al. 2011; $\mathrm{Wu}$ et al. 2009; Hwang and Hung 2005; Hossain 2004; Fragoulis et al. 2003, 2004). Use of these aggregates has contributed to the sustainable development by conserving energy, maximizing structural efficiency and increasing the

\footnotetext{
${ }^{1)}$ Lafarge Canada Inc., Toronto, ON, Canada.

${ }^{2)}$ Department of Civil Engineering, Ryerson University, Toronto, ON, Canada.

*Corresponding Author; E-mail: ahossain@ryerson.ca Copyright $($ The Author(s) 2015. This article is published with open access at Springerlink.com
}

service life of structural lightweight concrete (LWC). These benefits add to those of LWSCC to further support sustainable development and contribute to projects becoming Leadership in Energy and Environmental Design (LEED) certified (ESCSI 2004).

LWSCC is capable of filling up the formwork and encapsulate reinforcement by its self-weight without the need for additional compaction or external vibration. It has excellent segregation resistance, high flowability and passing ability at fresh state as well as better mechanical and durability properties in the hardened state. LWSCC has more continuous aggregate-paste contact zone and more moisture in the pores of aggregates for continued internal curingthese improvements lead to reduced concrete cracking and improved hardened properties (Holm 1994).

Although numerous investigations have been made on SCC and LWC, to the authors' best knowledge little research has been conducted on the design procedures and statistical modeling of LWSCC (Hwang et al. 2012; Bogas et al. 2012; Topçu and Uygunoğlu 2010; Andiç-Çakır and Hızal 2012).

Wu et al. (2009) investigated workability of LWSCC and its mix design using expanded shale as both fine and coarse aggregates. The study demonstrated that fixed aggregate contents can be used effectively in volumetric method to design LWSCC mixtures. An increase in the paste content of the mix increased the flow velocity but reduced resistance to segregation. Lachemi et al. (2009) developed three different classes of LWSCC mixtures using combination of blast furnace slag and expanded shale aggregates. Hwang and 
Hung (2005) evaluated the performance of LWSCC mixtures containing bottom ash, for varying water to cement ratio (w/c) and cement paste content. Kim et al. (2010) studied the semi-lightweight SCC characteristics using two types of coarse aggregates with different densities. Nine mixes were evaluated in terms of flowability, segregation resistance and filling capacity of fresh concrete. The mechanical properties of hardened LWSCC, such as compressive strength, splitting tensile strength, elastic modulus and density were assessed. Müller and Haist (2002) proposed three mix proportions for LWSCC and assessed their self-compacting properties. No significant difference in the mix proportion design was found compared with SCC except for the aggregate used.

Design procedures and statistical models for normal weight SCC have been developed in previous research studies (Khayat et al. 1998; Patel et al. 2004; Sonebi 2004a, b). However, lack of research studies on LWSCC technology warrants investigations. Authors' research based on statistical design approach to identify primary mix design parameters and their effects on relevant properties of $\mathrm{ESH}$ lightweight SCC (ESH-LWSCC) is a timely initiative. The knowledge of influence of mixture variables on fresh state and hardened characteristics (which is the objectives of the current study) is essential for successful development of ESH-LWSCCs.

This paper presents the development and validation of statistical models for the design of ESH-LWSCC mixtures with desired fresh and hardened properties. The developed statistical models can be used as tools for practical production of ESH-LWSCCs. The recommendations of this research will be useful for engineers, designers and manufacturers involving in the development, production and use of ESH-LWSCCs.

\section{Research Program}

This research was conducted in three phases. The phase I focused on the experimental study of the fresh and hardened properties of mathematically derived ESH-LWSCC mixes. Twenty concrete mixtures were designed. Three key mix design parameters namely water $(\mathrm{w})$ to binder $(\mathrm{b})$ ratio $(\mathrm{w} / \mathrm{b})$ (0.30-0.40), dosage of high range water reducing admixtures (HRWRA) (0.3-1.2\% by total content of binder) and total binder content (B) $\left(410-550 \mathrm{~kg} / \mathrm{m}^{3}\right)$ were selected to derive mathematical models for the design of ESH-LWSCC mixtures. The tested ESH-LWSCC properties were, slump flow, V-funnel flow time, J-ring flow diameter/height difference, L-box ratio, filling capacity, segregation resistance, unit weight and compressive strength.

Phase II focused on the model development. Based on the test results, the influences of various parameters $(\mathrm{w} / \mathrm{b}$, HRWRA\% and binder content) on ESH-LWSCC fresh and hardened properties were analyzed. The relative significance of these primary mixture design parameters and their coupled effects on relevant properties of ESH-LWSCCs were established. Afterward, statistical models were developed for prediction of these properties.
In phase III, the developed statistical models were used to derive optimized industrial class ESH-LWSCCs. ESHLWSCC mixtures were mathematically optimized to satisfy three classes of EFNARC industrial classifications and their performance was experimentally validated through fresh and hardened properties. In addition, the relationship between theoretical and experimental results was further investigated, where validation of the statistical models were performed.

\section{Phase-I Investigation}

\subsection{Materials}

ASTM Type I cement, Class F fly ash (FA) and silica fume (SF) were used. The physical and chemical properties of cement, FA and SF are presented in Table 1. FA and SF were incorporated into the mixture at a fixed percentage by mass of total binder at 12.5 and $7.5 \%$, respectively. Nominal sizes of 4.75 and $12 \mathrm{~mm}$ lightweight expanded shale were used as fine and coarse aggregates, respectively. Expanded shale produced by TXI aggregate company, Colorado, USA, was used. In manufacturing process, natural shale is expanded in an oil fired rotary kiln maintained between 1,900 and $1,200{ }^{\circ} \mathrm{C}$. At this temperature, the shale is in a semi-plastic state at which entrapped gases are formed and expansion results creating individual non-connecting air cells. After discharged from the kiln, it is cooled and stored. Table 1 presents the chemical properties of expanded shale aggregates, and Table 2 presents their grading and physical properties. Mineralogical composition of silica fume consists of an amorphous silica structure with very little crystalline particles. No undesirable trace elements were recorded in the manufacturer's material analysis sheet for all the materials.

The proposed ESH-LWSCC mixtures contained no viscosity-modifying admixture (VMA). The use of VMA is associated with reduction in paste volume which is believed to be detrimental to the LWSCC mixture stability, passing ability, filling ability and segregation resistance. Further, many successful LWSCC mixtures were developed without the use of VMA (Lachemi et al. 2009; Kim et al. 2010; Karahan et al. 2012). The silica fume is used to enhance the fresh properties as it helps to improve the cohesiveness and homogeneity of the LWSCCs; holding the lightweight coarse aggregates in place, and preventing them from floating. Further, fly ash and silica fume also enhance the durability characteristics of the mixture. A polycarboxylate ether type HRWRA with a specific gravity of 1.05 and total solid content of $26 \%$ was used as superplasticizer (SP).

\subsection{Mix Design Methodology and Mixture Proportions (Phase I)}

Twenty concrete mixtures were designed using the BoxWilson central composite design (CCD) method (Schmidt and Launsby 1994). Three input factors were used in the test program: $\mathrm{X}_{1}$ (water to binder ratio: w/b), $\mathrm{X}_{2}$ (percentage of HRWRA as a percentage of mass of total binder content), 
Table 1 Characteristics of cement fly ash, silica fume and expanded shale.

\begin{tabular}{|c|c|c|c|c|}
\hline & Cement & Fly ash & Silica fume & Expanded shale \\
\hline \multicolumn{5}{|c|}{ Chemical } \\
\hline $\mathrm{SiO}_{2}(\%)$ & 19.6 & 46.7 & 95.21 & 67.6 \\
\hline $\mathrm{Al}_{2} \mathrm{O}_{3}(\%)$ & 4.9 & 22.8 & 0.21 & 15.1 \\
\hline $\mathrm{Fe}_{2} \mathrm{O}_{3}(\%)$ & 3.1 & 15.5 & 0.13 & 4.1 \\
\hline $\mathrm{TiO}_{2}(\%)$ & - & - & - & 0.6 \\
\hline $\mathrm{CaO}(\%)$ & 61.4 & 5.8 & 0.23 & 2.2 \\
\hline $\mathrm{MgO}(\%)$ & 3 & - & - & 3.5 \\
\hline $\mathrm{SO}_{3}(\%)$ & 3.6 & 0.5 & 0.33 & 0.24 \\
\hline Alkalis as $\mathrm{Na}_{2} \mathrm{O}(\%)$ & 0.7 & 0.7 & 0.85 & 3.7 \\
\hline LOI (\%) & 2.3 & 2.2 & 1.97 & 3.06 \\
\hline \multicolumn{5}{|c|}{ Physical } \\
\hline Blaine $\left(\mathrm{cm}^{2} / \mathrm{g}\right)$ & 3,870 & 3,060 & 21,000 & - \\
\hline$+45 \mu \mathrm{m}(\%)$ & 3.00 & 17 & 2.85 & - \\
\hline Density $\left(\mathrm{g} / \mathrm{cm}^{3}\right)$ & 3.15 & 2.48 & 2.20 & - \\
\hline
\end{tabular}

Table 2 Grading and physical properties of aggregates.

\begin{tabular}{|c|c|c|c|c|}
\hline \multirow[t]{3}{*}{ Sieve size $(\mathrm{mm})$} & \multicolumn{4}{|c|}{$\%$ Passing } \\
\hline & \multicolumn{2}{|c|}{ ASTM C-330 specification } & \multicolumn{2}{|c|}{ E-shale } \\
\hline & Fine & Coarse & Fine & Coarse \\
\hline 13.20 & 100 & 100 & 100 & 100 \\
\hline 9.50 & $80-100$ & 100 & 100 & 91 \\
\hline 4.75 & $5-40$ & $85-100$ & 100 & 18.8 \\
\hline 2.36 & $0-20$ & - & 95 & 2.5 \\
\hline 1.18 & $0-10$ & $40-80$ & 65 & 1.6 \\
\hline 0.60 & - & - & 41 & 0.6 \\
\hline 0.30 & - & $10-35$ & 23.5 & 0.1 \\
\hline 0.15 & - & $5-25$ & 14.7 & 0 \\
\hline Bulk specific gravity (dry) & - & - & 1.40 & 1.33 \\
\hline Bulk specific gravity (SSD) & - & - & 1.81 & 1.71 \\
\hline $\begin{array}{l}\text { Dry loose bulk density } \\
\left(\mathrm{kg} / \mathrm{m}^{3}\right)\end{array}$ & $1,120(\max )$ & $880(\max )$ & 1,070 & 862 \\
\hline Absorption (\%) & - & - & 13 & 14 \\
\hline
\end{tabular}

and $\mathrm{X}_{3}$ (total binder content: $\mathrm{B}$ ). The ranges of the input factors were set at $0.30-0.40$ for $\mathrm{X}_{1}, 0.3-1.2 \%$ for $\mathrm{X}_{2}$, and $410-550 \mathrm{~kg} / \mathrm{m}^{3}$ for $\mathrm{X}_{3}$. Table 3 presents the coded value and limits of each factor.

The CCD method consists of three portions: the fraction factorial portion, the center portion, and the axial portion (Table 3). The mix design and statistical evaluation of the test results were performed at a 0.05 level of significance. Table 4 presents the mixture proportions for ESH-LWSCCs developed by the software.

\subsection{Casting of Test Specimens}

All concrete mixtures were prepared in 35 batches in a drum rotating mixer. Due to the high water absorption capacity, the expanded shale lightweight aggregates were pre-soaked for a minimum of $72 \mathrm{~h}$. The saturated surface dry expanded shale aggregates were mixed for 5 min with $75 \%$ of the mixing water then added to the cementitious materials and mixed for an additional minute. Finally, the remaining water and HRWRA were added to the mixture, and mixed for another $15 \mathrm{~min}$. Just after mixing, the slump flow, L-box, 
Table 3 Limit andcoded value of factors.

\begin{tabular}{|c|c|c|c|c|c|c|}
\hline \multirow[t]{2}{*}{ Factor } & \multirow[t]{2}{*}{ Range } & \multicolumn{5}{|c|}{ Coded value } \\
\hline & & -1.414 & -1 & 0 & +1 & +1.414 \\
\hline $\mathrm{X} 1=(\mathrm{w} / \mathrm{b})$ & $0.30-0.40$ & 0.28 & 0.30 & 0.35 & 0.40 & 0.42 \\
\hline $\begin{array}{c}\mathrm{X} 2=(\% \text { of } \\
\text { HRWRA })\end{array}$ & $0.3-1.2 \%$ & 0.11 & 0.30 & 0.75 & 1.2 & 1.39 \\
\hline $\mathrm{X} 3=(\mathrm{B}) \mathrm{kg} / \mathrm{m}^{3}$ & $410-550$ & 380 & 410 & 480 & 550 & 580 \\
\hline \multicolumn{7}{|c|}{ Factors } \\
\hline \multicolumn{2}{|c|}{ CCD portion } & \multicolumn{2}{|c|}{ Mixture } & $\mathrm{X} 1$ & $\mathrm{X} 2$ & $\mathrm{X} 3$ \\
\hline \multicolumn{2}{|c|}{ Fractional factorial } & \multicolumn{2}{|c|}{$1-8$} & \pm 1 & \pm 1 & \pm 1 \\
\hline \multicolumn{2}{|c|}{ Center point } & \multicolumn{2}{|c|}{$15-20$} & 0 & 0 & 0 \\
\hline \multicolumn{2}{|c|}{ Axial } & \multicolumn{2}{|c|}{$9-14$} & $0, \pm 1.414$ & $0, \pm 1.414$ & $0, \pm 1.414$ \\
\hline
\end{tabular}

Table 4 Mixture proportions for ESH-LWSCC (Phase I).

\begin{tabular}{|c|c|c|c|c|c|c|c|c|c|c|}
\hline \multirow[t]{2}{*}{ Mix no. } & \multirow[t]{2}{*}{$\mathrm{X} 1(\mathrm{w} / \mathrm{b})$} & \multirow{2}{*}{$\begin{array}{c}\mathrm{X} 2 \\
\text { (HRWRA) }\end{array}$} & \multirow[t]{2}{*}{ X3 (B) } & \multirow{2}{*}{$\begin{array}{l}\text { Cement } \\
\left(\mathrm{kg} / \mathrm{m}^{3}\right)\end{array}$} & \multirow[t]{2}{*}{ FA $\left(\mathrm{kg} / \mathrm{m}^{3}\right)$} & \multirow[t]{2}{*}{$\mathrm{SF}\left(\mathrm{kg} / \mathrm{m}^{3}\right)$} & \multirow{2}{*}{$\begin{array}{c}\text { HRWRA } \\
\left(1 / \mathrm{m}^{3}\right)\end{array}$} & \multirow{2}{*}{$\begin{array}{l}\text { Water } \\
\left(1 / \mathrm{m}^{3}\right)\end{array}$} & \multicolumn{2}{|c|}{ E-shale aggregate } \\
\hline & & & & & & & & & Coarse & Fine \\
\hline 1 & 0.40 & 1.2 & 550 & 440 & 69 & 41 & 6.6 & 220 & 385 & 613 \\
\hline 2 & 0.40 & 1.2 & 410 & 328 & 51 & 31 & 4.9 & 164 & 456 & 726 \\
\hline 3 & 0.40 & 0.3 & 550 & 440 & 69 & 41 & 1.6 & 220 & 388 & 618 \\
\hline 4 & 0.40 & 0.3 & 410 & 328 & 51 & 31 & 1.2 & 164 & 459 & 730 \\
\hline 5 & 0.30 & 1.2 & 550 & 440 & 69 & 41 & 6.6 & 165 & 422 & 672 \\
\hline 6 & 0.30 & 1.2 & 410 & 328 & 51 & 31 & 4.9 & 123 & 484 & 771 \\
\hline 7 & 0.30 & 0.3 & 550 & 440 & 69 & 41 & 1.6 & 165 & 426 & 678 \\
\hline 8 & 0.30 & 0.3 & 410 & 328 & 51 & 31 & 1.2 & 123 & 487 & 775 \\
\hline 9 & 0.42 & 0.75 & 480 & 384 & 60 & 36 & 3.6 & 201 & 415 & 661 \\
\hline 10 & 0.28 & 0.75 & 480 & 384 & 60 & 36 & 3.6 & 134 & 461 & 734 \\
\hline 11 & 0.35 & 1.39 & 480 & 384 & 60 & 36 & 6.7 & 168 & 436 & 695 \\
\hline 12 & 0.35 & 0.11 & 480 & 384 & 60 & 36 & 0.5 & 168 & 440 & 701 \\
\hline 13 & 0.35 & 0.75 & 580 & 464 & 73 & 44 & 4.3 & 203 & 391 & 622 \\
\hline 14 & 0.35 & 0.75 & 380 & 304 & 48 & 29 & 2.9 & 133 & 486 & 773 \\
\hline 15 & 0.35 & 0.75 & 480 & 384 & 60 & 36 & 3.6 & 168 & 438 & 698 \\
\hline 16 & 0.35 & 0.75 & 480 & 384 & 60 & 36 & 3.6 & 168 & 438 & 698 \\
\hline 17 & 0.35 & 0.75 & 480 & 384 & 60 & 36 & 3.6 & 168 & 438 & 698 \\
\hline 18 & 0.35 & 0.75 & 480 & 384 & 60 & 36 & 3.6 & 168 & 438 & 698 \\
\hline 19 & 0.35 & 0.75 & 480 & 384 & 60 & 36 & 3.6 & 168 & 438 & 698 \\
\hline 20 & 0.35 & 0.75 & 480 & 384 & 60 & 36 & 3.6 & 168 & 438 & 698 \\
\hline
\end{tabular}

V-funnel, J-ring flow, filling capacity, sieve segregation, and unit weight tests were conducted. Ten $100 \times 200 \mathrm{~mm}$ cylinders from each batch were cast for compressive strength determination. All ESH-LWSCC specimens were cast without any compaction or mechanical vibration. After casting, all the specimens were covered with plastic sheets and water-saturated burlap and left at room temperature for $24 \mathrm{~h}$. They were then demolded and transferred to the moist curing room, and maintained at $23 \pm 2{ }^{\circ} \mathrm{C}$ and $100 \%$ relative humidity until testing. The cylinders for the oven dry unit weight test were stored in lime-saturated water for 28 days prior to transfer to the oven at $100{ }^{\circ} \mathrm{C}$. The cylinders 
for the air dry unit weight test were stored in room temperature for 28 days.

\subsection{Testing Procedures}

All fresh tests were conducted as per EFNARC SelfCompacting Concrete Committee test procedures (EFNARC 2005). The slump flow test was conducted to assess the workability of concrete without obstructions to determine flow diameter. The deformability of ESH-LWSCC was measured using the V-funnel test, where flow time under gravity was determined. The filling capacity, J-ring and L-box tests determined the passing ability of concrete. The sieve segregation resistance (SSR) test was conducted according to EFNARC test procedures: $5 \mathrm{~kg}$ of fresh concrete was poured over $5 \mathrm{~mm}$ mesh, and the mass of the mortar passing through the sieve was recorded. The fresh unit weight was tested according to per ASTM C 138 (2010) and both air dry and oven dry densities were determined according to ASTM C 567 (2011). The compressive strength of ESH-LWSCC mixtures was determined by using $100 \times 200 \mathrm{~mm}$ cylinders, as per ASTM C 39 (2011)
3.5 Phase I: Test Results, Analysis and Discussion

\subsubsection{Fresh and Hardened Properties of ESH- LWSCC Mixtures}

The fresh and hardened properties of ESH-LWSCC mixtures are summarized in Table 5. Ranges of the test values for ESH-LWSCC mixtures were between 365 and $850 \mathrm{~mm}$ for slump flow, 1.2 and $24 \mathrm{~s}$ for V-funnel flow time, 360 and $850 \mathrm{~mm}$ for J-ring flow, 0 and $14 \mathrm{~mm}$ for J-ring height difference, 0.28 and 1 for L-box ratio, 29 and $100 \%$ for filling capacity and 4 and $38 \%$, for SSR. The compressive strength ranged from 20 to 40 and 28 to $53 \mathrm{MPa}$ at 7 and 28 days, respectively. The fresh unit weight ranged from 1,742 to $1,892 \mathrm{~kg} / \mathrm{m}^{3}$ and the 28 -day air dry density values were less than $1,840 \mathrm{~kg} / \mathrm{m}^{3}$ which classified all ESHLWSCC mixtures as lightweight concrete. It is understood that the long-term strength of LWSCC mixes is very important since FA is used. This will be subject matter of future research studies in association with long-term durability properties of LWSCC mixes.

In order to qualify as SCC, the mixes should satisfy EFNARC industrial classifications, with $550-850 \mathrm{~mm}$

Table 5 Test results on fresh and hardened properties.

\begin{tabular}{|c|c|c|c|c|c|c|c|c|c|c|c|c|}
\hline \multirow[t]{2}{*}{ Mix no. } & \multirow{2}{*}{$\begin{array}{l}\text { Slump } \\
\text { flow } \\
(\mathrm{mm})\end{array}$} & \multirow[t]{2}{*}{$\begin{array}{l}\text { V-funnel } \\
\text { (s) }\end{array}$} & \multirow{2}{*}{$\begin{array}{l}\text { J-ring } \\
\text { flow } \\
(\mathrm{mm})\end{array}$} & \multirow{2}{*}{$\begin{array}{c}\text { J-ring } \\
\text { height } \\
\text { diff } \\
(\mathrm{mm})\end{array}$} & \multirow[t]{2}{*}{$\begin{array}{l}\text { L-box } \\
\text { ratio }\end{array}$} & \multirow{2}{*}{$\begin{array}{c}\text { Filling } \\
\text { capacity } \\
(\%)\end{array}$} & \multirow[t]{2}{*}{$\begin{array}{l}\text { SSR } \\
(\%)\end{array}$} & \multicolumn{2}{|c|}{$\begin{array}{c}\text { Compressive strength } \\
(\mathrm{MPa})\end{array}$} & \multicolumn{3}{|c|}{ 28-day Unit weight $\left(\mathrm{kg} / \mathrm{m}^{3}\right)$} \\
\hline & & & & & & & & 7-days & 28-days & Fresh & Air dry & Oven dry \\
\hline 1 & 850 & 1.6 & 850 & 0 & 1.00 & 100 & 14 & 27 & 36 & 1,800 & 1,688 & 1,650 \\
\hline $2^{\mathrm{a}}$ & 810 & 1.2 & 770 & 0 & 1.00 & 100 & 38 & 21 & 28 & 1,826 & 1,700 & 1,645 \\
\hline $3^{\mathrm{a}}$ & 530 & 1.8 & 540 & 2 & 0.55 & 58 & 6 & 29 & 40 & 1,840 & 1,728 & 1,672 \\
\hline $4^{a}$ & 535 & 5.6 & 510 & 5 & 0.53 & 58 & 24 & 23 & 31 & 1,850 & 1,740 & 1,690 \\
\hline $5^{\mathrm{a}}$ & 640 & 11.1 & 650 & 2 & 0.77 & 76 & 10 & 34 & 48 & 1,859 & 1,747 & 1,690 \\
\hline $6^{\mathrm{a}}$ & 625 & 11.9 & 590 & 4 & 0.63 & 67 & 20 & 31 & 43 & 1,866 & 1,754 & 1,707 \\
\hline $7^{\mathrm{a}}$ & 365 & 19.7 & 370 & 9 & 0.31 & 29 & 4 & 38 & 51 & 1,873 & 1,761 & 1,704 \\
\hline $8^{\mathrm{a}}$ & 380 & 18.5 & 360 & 14 & 0.37 & 31 & 6 & 34 & 46 & 1,751 & 1,611 & 1,566 \\
\hline $9^{a}$ & 810 & 1.4 & 805 & 0 & 1.00 & 100 & 30 & 20 & 28 & 1,770 & 1,658 & 1,573 \\
\hline $10^{\mathrm{a}}$ & 395 & 24.0 & 415 & 5 & 0.28 & 31 & 7 & 40 & 53 & 1,807 & 1,667 & 1,623 \\
\hline $11^{\mathrm{a}}$ & 820 & 3.2 & 795 & 0 & 1.00 & 100 & 24 & 26 & 40 & 1,817 & 1,684 & 1,630 \\
\hline $12^{\mathrm{a}}$ & 390 & 6.0 & 390 & 8 & 0.33 & 29 & 7 & 32 & 46 & 1,779 & 1,652 & 1,603 \\
\hline $13^{\mathrm{a}}$ & 595 & 6.5 & 630 & 0 & 0.72 & 73 & 6 & 36 & 51 & 1,892 & 1,765 & 1,729 \\
\hline $14^{\mathrm{a}}$ & 755 & 1.9 & 715 & 0 & 1.00 & 100 & 34 & 22 & 31 & 1,742 & 1,630 & 1,601 \\
\hline 15 & 675 & 3.6 & 680 & 2 & 1.00 & 98 & 13 & 31 & 44 & 1,807 & 1,695 & 1,635 \\
\hline 16 & 705 & 3.7 & 710 & 2 & 0.98 & 100 & 11 & 34 & 48 & 1,789 & 1,676 & 1,604 \\
\hline 17 & 685 & 4.0 & 680 & 1 & 1.00 & 99 & 12 & 32 & 44 & 1,779 & 1,667 & 1,611 \\
\hline 18 & 700 & 3.7 & 700 & 1 & 0.97 & 97 & 13 & 31 & 45 & 1,782 & 1,670 & 1,614 \\
\hline 19 & 685 & 3.5 & 680 & 1 & 1.00 & 97 & 10 & 33 & 46 & 1,787 & 1,662 & 1,597 \\
\hline 20 & 705 & 4.1 & 700 & 2 & 0.99 & 99 & 12 & 31 & 43 & 1,800 & 1,675 & 1,625 \\
\hline
\end{tabular}

\footnotetext{
${ }^{a}$ Mixture disqualified as LWSCC
} 
slump flow (Nagataki and Fujiwara 1995), less than $8 \mathrm{~s}$ of V-funnel time, $80-100 \%$ of filling capacity, greater than 0.8 of L-box ratio (Sonebi et al. 2000), and less than $20 \%$ of segregation resistance (EFNARC 2005). To be classified as LWSCC, a mix should satisfy EFNARC-SCC industrial classifications as well as it should develop a minimum 28-day compressive strength of 17.2 $\mathrm{MPa}$ and attain an air dry unit weight of less than $1,840 \mathrm{~kg} / \mathrm{m}^{3}$ (ACI Committee 213R 2003).

Using basic knowledge of concrete technology, it is expected that fresh and hardened properties of LWSCC mixtures will be influenced by the same parameters and in same way as normal weight SCC mixtures, with exception to the V-funnel time. Theoretically speaking, when reducing the unit weight to less than $1,840 \mathrm{~kg} / \mathrm{m}^{3}$, it might be expected that the velocity of flow can be affected; leading to lower V-funnel time values than the ones reported for normal weight SCC.

The filling capacity test is more relevant for assessing the deformability of SCC among closely spaced obstacles. A filling capacity between 50 and $95 \%$ indicates moderate to excellent flowability among closely spaced obstacles (Khayat et al. 2002). For a desirable SCC mixture performance, different range of $\mathrm{V}$-funnel time is suggested by researchers: between 3 and $7 \mathrm{~s}$, between 2.2 and $5.4 \mathrm{~s}$ and between 2.1 and $4.2 \mathrm{~s}$ (Khayat et al. 2002; Bouzoubaa and Lachemi, 2001; Ghezal and Khayat 2002).

It is reported that the SCC with L-box ratio greater than 0.8 exhibited good performance without blocking, hence 0.8 is considered as the lower critical limit for a mix to be SCC ratio (Sonebi et al. 2000). According to several studies, the L-box and the filling capacity test results should be simultaneously considered to evaluate the concrete passing ability through heavily reinforced sections without the need of vibration. One of the most important requirements for any SCC is that the aggregates should not be segregated from the paste and the mix should remain homogeneous during the production and placement. It is also equally important that the particles move with the matrix as a cohesive fluid during the flow of SCC. A stable SCC should exhibit a segregation index less than $10 \%$ (Khayat et al. 1998). However it is expected that the allowable segregation index for LWSCC should be higher than normal weight SCC. Therefore, the limits for fresh state properties of LWSCC mixtures should be changed. For LWSCC mixtures, the criteria can be as follows: slump flow diameter $(550-850 \mathrm{~mm}), \mathrm{V}$-funnel time $(0-25 \mathrm{~s})$, L-box ratio ( $\geq 0.80)$, sieve segregation resistance $(0-20 \%), 28$-day air dry unit weight $\left(<1,840 \mathrm{~kg} / \mathrm{m}^{3}\right)$ and 28-day compressive strength $(>17.2 \mathrm{MPa})$.

From the results of the present study (Table 5), mixes 3-8 and 10-13 exhibited low flowability, poor workability and passing ability as the slump flow diameter, V-funnel time and L-box ratio were below the acceptable EFNARC performance criteria for SCC (EFNARC 2005). On the other hand, mixes 2, 4, 9, 11 and 14 are considered segregated mixes due to high segregation index beyond the prescribe limits. Mixes 1, 6, 15, 16, 17, 18, 19 and 20 met all SCC fresh performance with no sign of segregation (Table 5). Out of 20 tested mixtures, only 8 mixtures satisfied the outlined criteria for structural LWSCC. This demonstrates the significant challenges associated with the development of LWSCC mixtures.

\section{Phase II: Influence of Mix Design Parameters and Development of Statistical Models}

The fresh and hardened properties of twenty ESHLWSCC mixtures obtained in Phase I were used to analyze the influence of mix design parameters and development of statistical models.

\subsection{Influence of Mix Design Parameters on Fresh and Hardened Properties \\ 4.1.1 Influence on the Slump Flow}

Figure 1 presents contour diagrams of the slump flow diameter changes of ESH-LWSCC mixtures depending on the water to binder ratio and total binder content. According to Fig. 1, an increase in the w/b from 0.3 to 0.4 significantly increased the slump flow. However, at fixed HRWRA\% the slump flow range got limited with the increase of binder content. For example, when the HRWRA\% was fixed at $0.75 \%$ and the binder content was increased to $550 \mathrm{~kg} / \mathrm{m}^{3}$, the maximum predicted slump flow was limited to $700 \mathrm{~mm}$. This was due to the increased demand of HRWRA in order to maintain same slump flow diameter with higher binder content.

The combined effects of $w / b$ and HRWRA have significant influence on the slump flow diameter as shown in Fig. 2. An increase in the HRWRA from 0.3 to $1.2 \%$ (by total content of binder) and $\mathrm{w} / \mathrm{b}$ from 0.3 to 0.4 significantly increased the slump flow when high binder content $(480 \mathrm{~kg}$ / $\mathrm{m}^{3}$ ) was used.

Great positive effect of the coupled parameters (w/b and HRWRA) in increasing the slump flow was observed with the ESH-LWSCC mixtures. For example, when both parameters (w/b and HRWRA) were maximized at $1.2 \%$ and 0.40 , the maximum predicted slump flow for $\mathrm{ESH}$ mixtures was $850 \mathrm{~mm}$. This can be attributed to the aggregate shape/gradation and packing density because a lower amount of fluidity is needed to achieve high workability for high-packing density mixture, as in the case of ESH aggregates. According to Assaad and Khayat (2006), the w/b is closely related to flowability of concrete and an increase in $\mathrm{w} / \mathrm{b}$ improves the flowability of the concrete. Sonebi et al. (2007) state that the SCC fresh properties are significantly influenced by the dosage of water and HRWRA. It is expected that LWSCC mixtures will exhibit similar behaviour compared with normal weight SCC mixtures under the influence of HRWRA.

\subsubsection{Influence on the V-funnel Flow Time}

An increase of the $\mathrm{w} / \mathrm{b}$ from 0.3 to 0.4 significantly reduced the V-funnel flow time whereas an increase of HRWRA from 0.3 to $1.2 \%$ only slightly reduced the 
Design-Expert $\circledast$ Software

Slump Flow (mm)

- Design Points

$\prod_{365}^{850}$

$\mathrm{X} 1=\mathrm{A}: \mathbf{w} / \mathbf{b}$

$\mathrm{X} 2=\mathrm{C}: \mathrm{B}$

Actual Factor

B: $H R W R A=0.75$

A: w/b

B: HRWRA

C: Binder content (B)

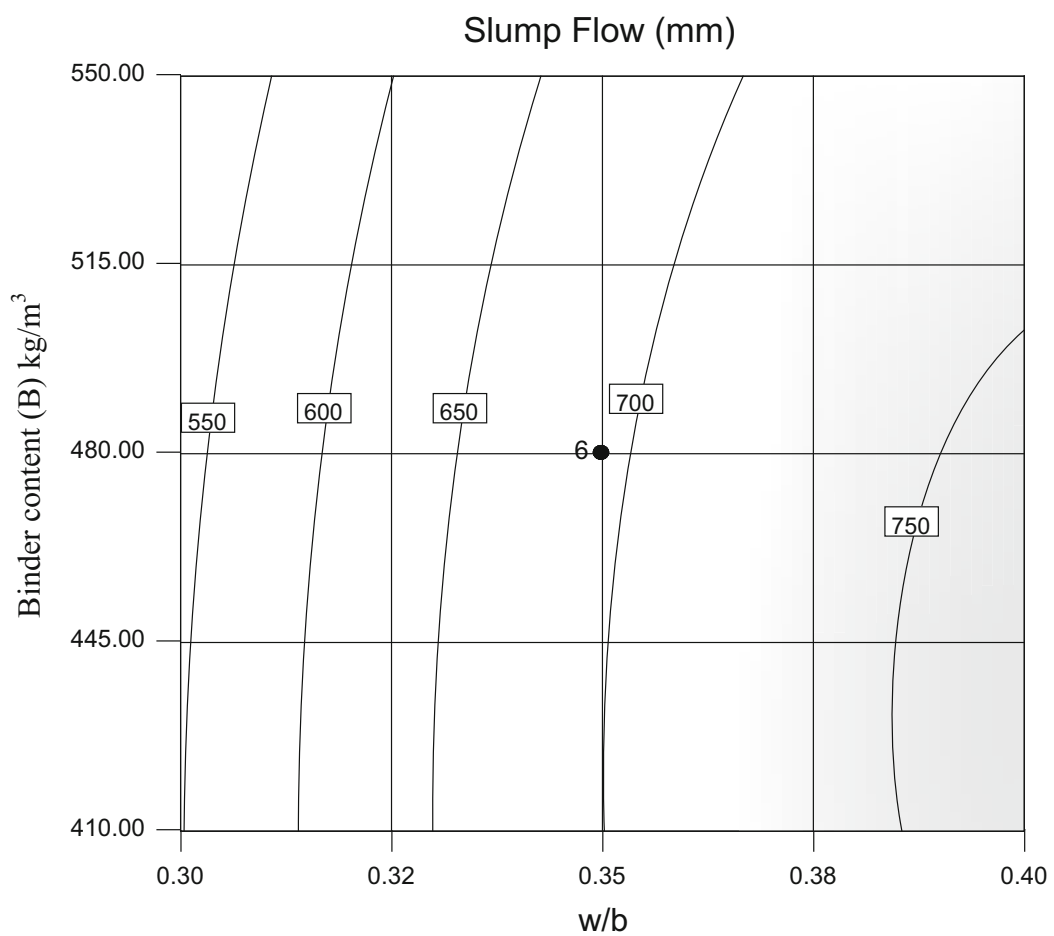

Fig. 1 Contours of slump flow changes of ESH-LWSCCs with w/b, total binder content and HRWRA at $0.75 \%$.

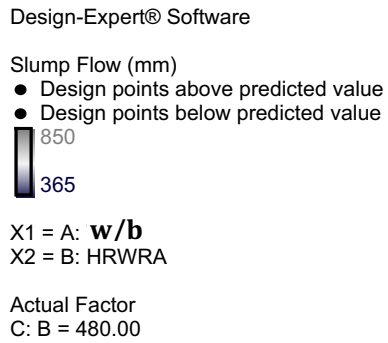

$\mathrm{A}: \mathrm{w} / \mathrm{b}$

B: HRWRA

$\mathrm{C}$ : Binder content $(\mathrm{B})$

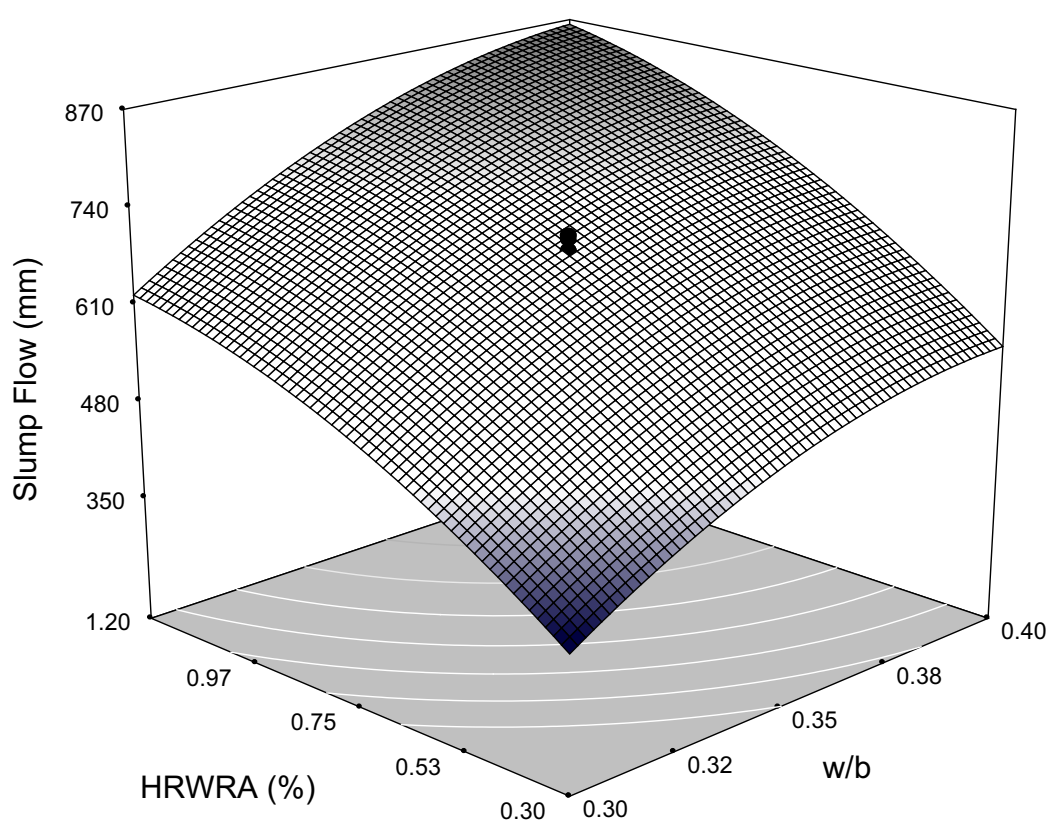

Fig. 2 Effect of w/b, HRWRA and total binder content at $480 \mathrm{~kg} / \mathrm{m}^{3}$ on the slump flow of ESH-LWSCCs.

V-funnel flow time. However, combined maximum increase of both $w / b$ and HRWRA parameters resulted in a substantial reduction of the V-funnel flow time (below $2 \mathrm{~s}$ ) at given binder content. This observation is in agreement with the conclusion of previous SCC statistical workability study (Sonebi et al. 2007). The V-funnel flow time is indicative of the viscosity of the LWSCC mixture-the higher the flow times the more viscous and less workable is the mix. Changes of V-funnel flow time with $w / b$ and HRWRA are depicted in Fig. 3. The effect of w/b and total binder content on the V-funnel flow time of ESH-LWSCC mixtures is plotted in Fig. 4. It can be concluded that an increase of $w / b$ from 0.3 to 0.4 significantly decreased the $\mathrm{V}$-funnel flow time. However, only a slight increase in flow time was 


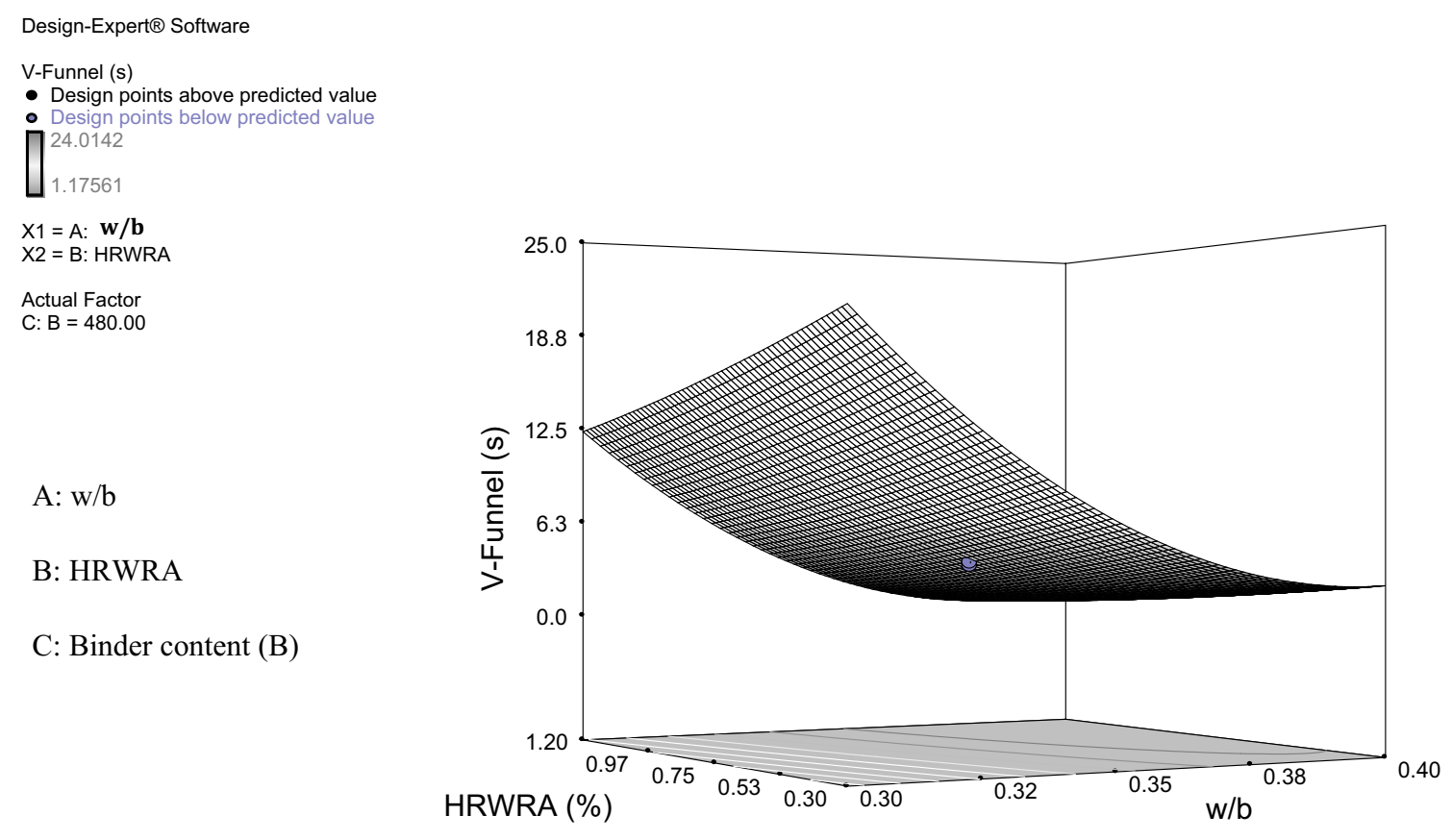

Fig. 3 Effect of w/b, HRWRA and total binder content at $480 \mathrm{~kg} / \mathrm{m}^{3}$ on the V-funnel time of ESH-LWSCCs.

observed with the increase of binder content at a given HRWRA\%. This can be attributed to low internal friction (higher excess paste volume) in the ESH mixes.

\subsubsection{Influence on the L-Box Ratio}

The L-box ratio showed a similar trend of variation as slump flow. An increase of w/b from 0.3 to 0.4 and HRWRA from 0.3 to $1.2 \%$ significantly increased the L-box ratio when a high binder content of $480 \mathrm{~kg} / \mathrm{m}^{3}$ was used. Figure 5 presents the slump flow changes of ESH-LWSCC mixtures depending on the w/b and HRWRA. According to Hwang et al. (2006), a combination of the slump flow and the L-box ratio can be used to assess filling capacity of SCC for quality control and design of SCC for placement in restricted sections or congested elements.

Figure 6 presents contour diagrams of the L-box ratio of ESH-LWSCC mixtures depending on the $\mathrm{w} / \mathrm{b}$ and total binder, respectively. It can be suggested that as the total binder content is increased, the L-box ratio is reduced for a given HRWRA\%. Previous research demonstrated the relationship between w/b, HRWRA, volume of coarse aggregate and L-box ratio for normal weight SCC mixtures where all three parameters are found to significantly influence the L-box ratio (Sonebi et al. 2007).

\subsubsection{Influence on the Segregation Resistance}

Figure 7 shows that the increase of the binder content appeared to be very effective in increasing the segregation resistance. The increase in binder content enhanced the packing density of mixtures and resulted in a reduction in segregation. This is also attributed to the increased cohesiveness and viscosity of the concrete mixture at high binder content. Similar conclusions were drawn in previous normal weight SCC statistical studies (Patel et al. 2004; Khayat et al.
2000). Figure 8 illustrates the trade-off between variation of the $\mathrm{w} / \mathrm{b}$ and HRWRA on the segregation resistance of ESHLWSCC mixtures at a given binder content $\left(480 \mathrm{~kg} / \mathrm{m}^{3}\right)$. These contours show that increasing one or both parameters $\mathrm{w} / \mathrm{b}$ and HRWRA (from 0.3 to 0.4 and from 0.3 to $1.2 \%$, respectively), would significantly reduce the segregation resistance of ESH-LWSCC mixtures.

\subsubsection{Influence on Other Properties}

For all mixes, the filling capacity and J-ring flow/J-ring height difference were positively influenced by w/b and HRWRA. An increase of either or both parameters led to an increase in the measured responses/properties. However, an increase in the binder content alone affects the results negatively_-showing a decrease in the measured responses.

The aggregate density played a major role in affecting the fresh unit weight of the mixes. As for the influence of the examined parameters on the response, the fresh unit weight was influenced mainly by the binder content - as the binder content increased the fresh unit weight increased and vice versa. Only the total binder content affected the results of the 28-day air and oven dry unit weights of ESH mixtures. An increase in the total binder content increased both unit weights. This behavior might be attributed to the high absorption rate of aggregates (above $13 \%$ ) that slowed the evaporation rate of water from the mixture. The HRWRA\% did not have an effect on the results.

For all developed mixes, 7-day compressive strengths were affected by all three parameters (w/b, HRWRA and total binder content). As the binder increased, the 7-day strength increased. In contrast, as the either or both HRWRA (\%) and $w / b$ increased the 7-day strength decreased. Nevertheless, it was expected that HRWRA\% should not have 
Design-Expert@ Software

V-Funnel (s)

- Design Points

24.0142

1.17561

$\mathrm{X} 1=\mathrm{A}: \mathbf{w} / \mathbf{b}$

$\mathrm{X} 2=\mathrm{C}: \mathrm{B}$

Actual Facto

B: $H R W R A=0.75$

$\mathrm{A}: \mathrm{w} / \mathrm{b}$

B: HRWRA

C: Binder content (B)

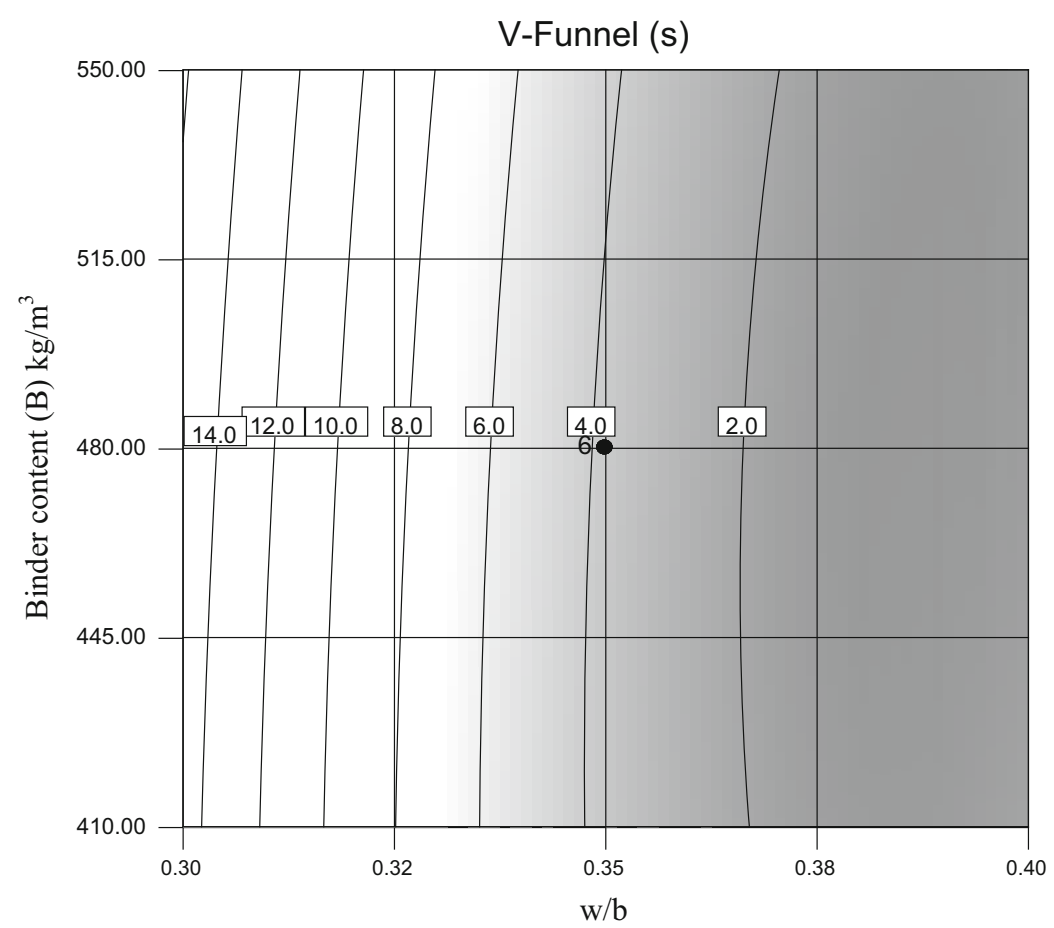

Fig. 4 Contours of V-funnel changes of ESH-LWSCC mixes with w/b, total binder content and HRWRA at $0.75 \%$.

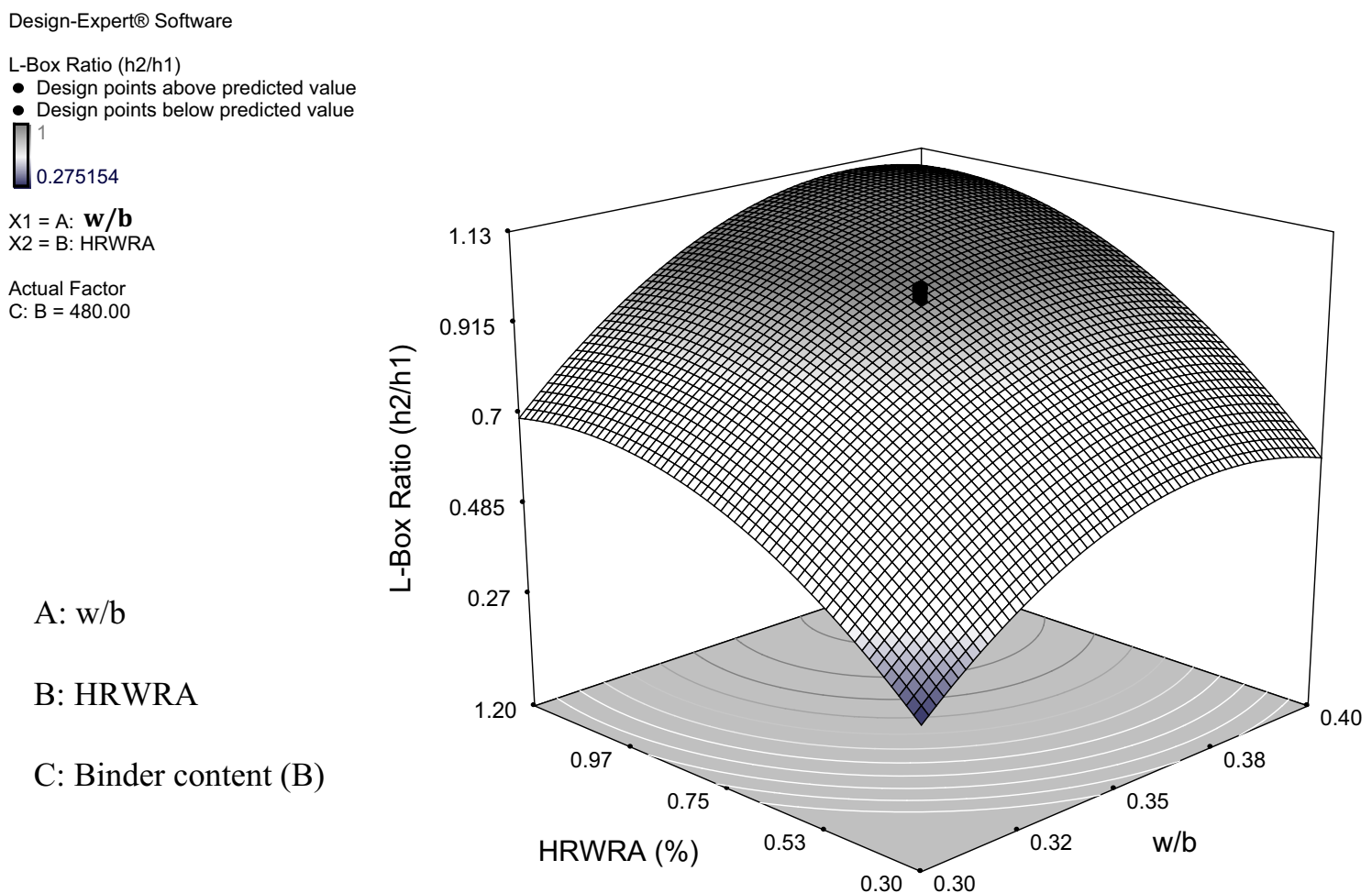

Fig. 5 Effect of w/b, HRWRA and total binder content at $480 \mathrm{~kg} / \mathrm{m}^{3}$ on the L-box of ESH-LWSCCs.

any influence on the 7-day strength. This is because HRWRA\% effect is typically weakened away after $24-48 \mathrm{~h}$. On the other hand, the 28-day compressive strengths were mainly affected by $\mathrm{w} / \mathrm{b}$ and total binder content. An increase in $\mathrm{w} / \mathrm{b}$ decreased the 28-day strengths, while an increase in total binder content increased the compressive strength which is agreement with basic knowledge of concrete technology regardless of the concrete type.

\subsection{Statistical Evaluation of Test Results}

A model analysis of the response was carried out to determine the effectiveness of test parameters in controlling 
Design-Expert $₫$ Software

L-Box Ratio (h2/h1)

- Design Points

0.275154

$\mathrm{X} 1=\mathrm{A}: \mathbf{w} / \mathbf{b}$ X2 = C: B

Actual Factor B: $H R W R A=0.75$

A: w/b

B: HRWRA

$\mathrm{C}$ : Binder content $(\mathrm{B})$

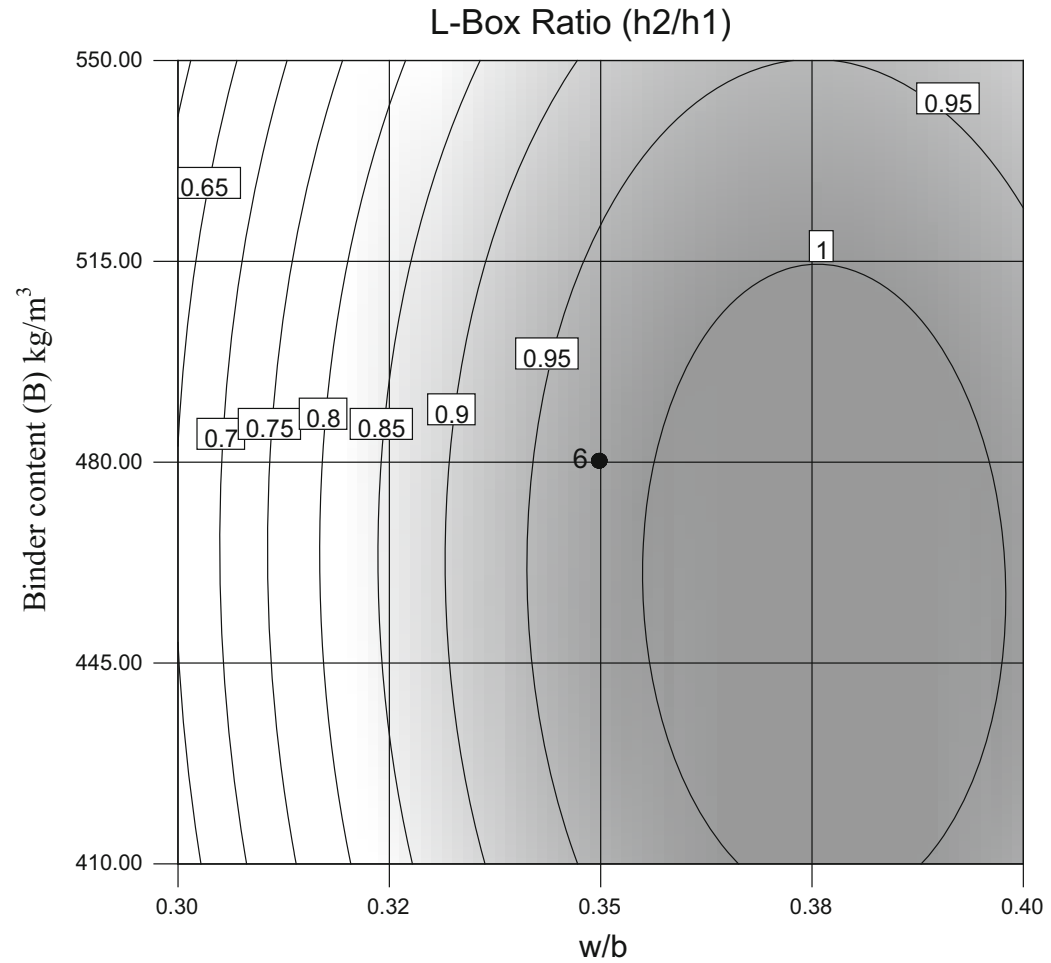

Fig. 6 Contours of L-box ratio changes of ESH-LWSCCs with w/b, total binder content and HRWRA at $0.75 \%$.

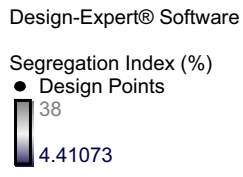

$\mathrm{X} 1=\mathrm{A}: \mathbf{w} / \mathbf{b}$

$\mathrm{X} 2=\mathrm{C}: \mathrm{B}$

Actual Factor B: HRWRA $=0.75$

A: w/b

B: HRWRA

C: Binder content (B)
Segregation Index (\%)

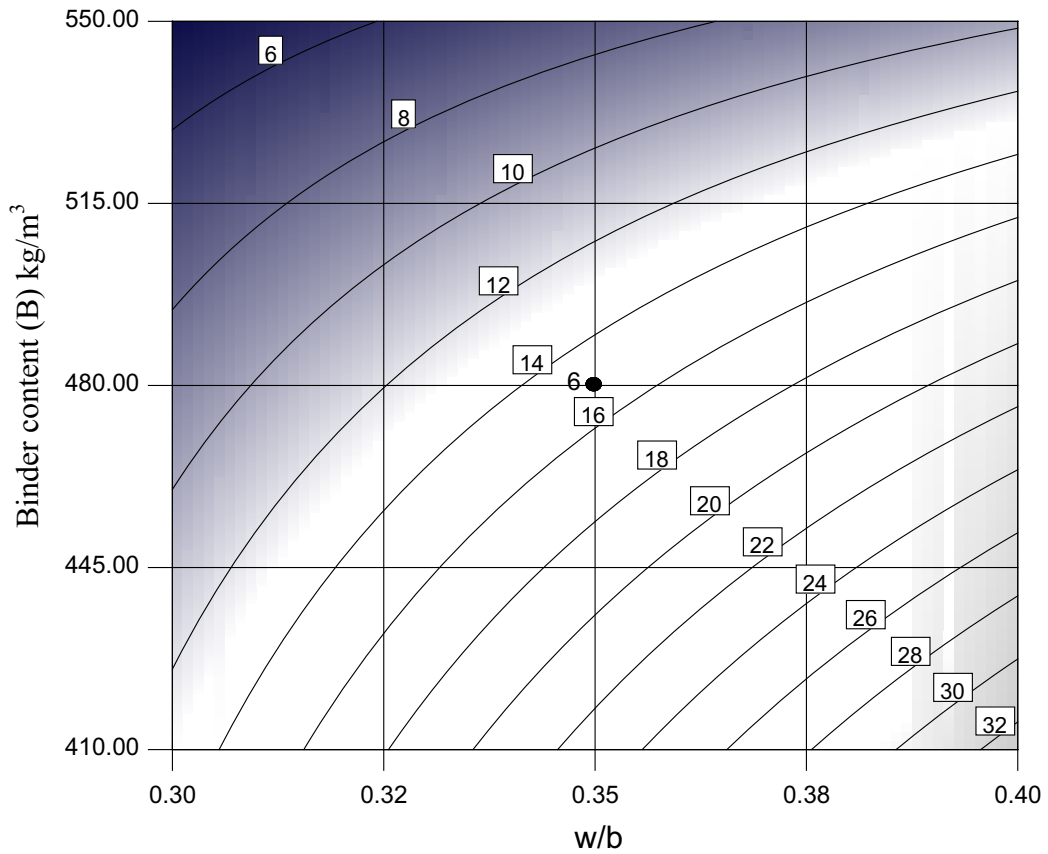

Fig. 7 Contours of segregation resistance changes of ESH-LWSCC mixes with w/b, total binder content and HRWRA at $0.75 \%$.

the ESH-LWSCC properties. Using GLM-ANOVA, the measured fresh and hardened properties of ESH-LWSCCs such as slump flow, V-funnel flow time, etc., were given as the dependent variables while the experimental test parameters ("w/b", "HRWRA\%", and "B") were selected as the independent factors/variables. The general linear model analysis of variance was performed and the effective test parameters and their percent contributions on the above mentioned properties of ESH-LWSCCs were determined. Table 6 summarized all the relevant data from statistical evaluation.

The $p$ value in Table 6 shows the significance of the given test parameters on the test results. If a system has a $p$ value (Probabilities) of $\leq 0.05$ it is accepted as a significant factor 


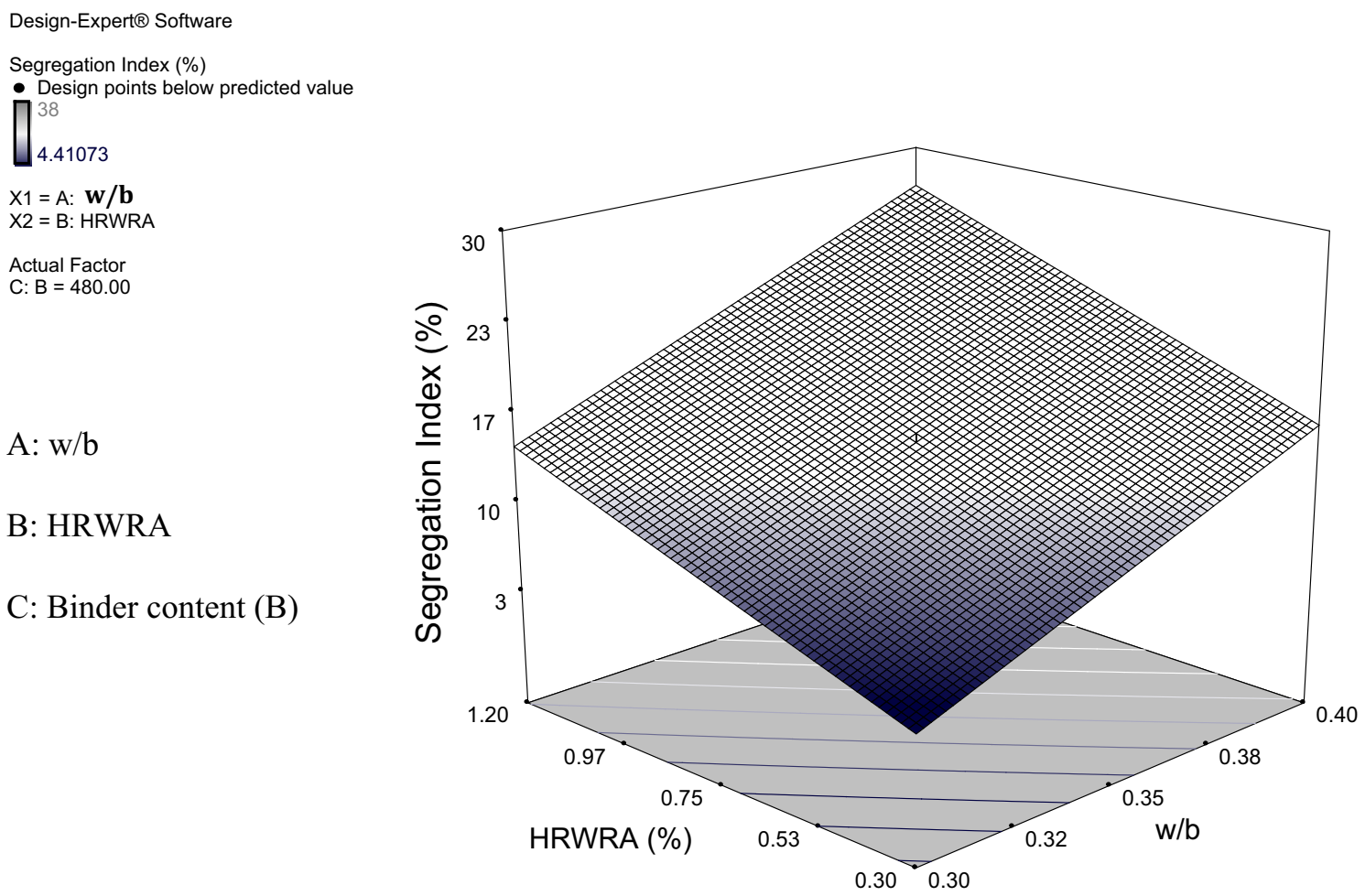

Fig. 8 Effect of w/b, HRWRA and total binder content at $480 \mathrm{~kg} / \mathrm{m}^{3}$ on the SSR of ESH-LWSCC mixes.

on the test result, as evidence indicates that the parameter is not zero; that is, the contribution of the proposed parameter has a highly significant influence on the measured response (Patel et al. 2004; Sonebi 2004a, b). The contributions of the each parameters on the measured test results are presented in Table 6, where the effectiveness of the independent parameters on the measured response is calculated. The higher the contribution, the higher the effectiveness of the parameter on the response, equally, the lower the contributions the lower effect on the response.

Analysis of the statistical parameters of the derived model, along with the relative significance, and the contribution $\%$ of each parameter on the results are given in Table 6 . The $R^{2}$ values of the ESH-LWSCC response models for the slump flow, V-funnel flow, J-Ring flow, J-Ring height difference, L-box, filling capacity, sieve segregation resistance, 7-day compressive strength, 28-day compressive strength, fresh unit weight, 28-day air dry unit weight, and 28-day oven dry unit weight were found to be $0.96,0.97,0.96,0.94,0.94$, $0.95,0.90,0.88,0.93,0.73,0.56$, and 0.75 , respectively.

Statistically significant models for ESH-LWSCCs with a high correlation coefficient $R^{2}>0.90$ were established for the slump flow, V-funnel, J-ring, J-ring height difference, L-box, filling capacity, sieve segregation resistance and 28-day compressive strength. A relatively lower $R^{2}$ values of $0.88,0.73$ and 0.75 were obtained for the 7 -day compressive strength fresh and 28-day oven dry unit weights, respectively. Low $R^{2}$ of 0.56 was obtained for 28 -day air dry unit weight (Table 6).

As for the significance of the parameters on the responses, for example for the slump flow; the order of influence of the test variables is: the dosage of HRWRA, w/b, and the binder content. The dosage of HRWRA had the greatest effect on the slump flow. The effect of binder content was insignificant to the response. This can be attributed to the fact that flowability is driven by HRWRA dose and w/b rather than the binder content. In fact, to secure the same slump flow with more binder content, an increase of both HRWRA and $\mathrm{w} / \mathrm{b}$ is necessary.

As for the V-funnel time, the order of influence of the test variables on the response is: w/b, the dosage of HRWRA and then binder content. Whereas the dosage of HRWRA, w/b, and the binder content in this order of influence, are contributing to the responses of J-ring flow, J-ring height different, L-box and filling capacity. The sieve segregation resistance response is greatly influenced by the total binder content, followed by $w / b$ and then the dosage of HRWRA. The contribution $\%$ of each parameter on the rest of the results is given in Table 6 .

The high correlation coefficient of responses demonstrates excellent correlation, where it can be considered that at least $95 \%$ of the measured values can be accounted for with the proposed models (Patel et al. 2004; Sonebi 2004a, b).

\subsection{Mathematical Formulation of ESH-LWSCC Properties}

The mathematical relationship between the independent variables and the responses can be estimated using the model. Linear or quadratic relationships are simplified by using a backward stepwise technique. Evaluating the contribution of each parameter and its significant influence on the response is a key tool used in accepting certain contribution (Whitcomb and Anderson 2004; Pradeep 2008). 
Table 6 Analysis of GLM-ANOVA model.

\begin{tabular}{|c|c|c|c|c|c|c|c|c|}
\hline \multirow{2}{*}{$\begin{array}{c}\text { Dependent } \\
\text { variable }\end{array}$} & \multirow{2}{*}{$\begin{array}{c}\text { Source of } \\
\text { variation }\end{array}$} & \multicolumn{5}{|c|}{ Statistical parameters } & \multirow[t]{2}{*}{ Significant } & \multirow{2}{*}{$\begin{array}{c}\text { Contribution } \\
(\%)\end{array}$} \\
\hline & & DOF & Sum of Square & Mean square & $\mathrm{F}$ & $p$ value & & \\
\hline \multirow[t]{3}{*}{ "Slump flow } & $\mathrm{w} / \mathrm{b}$ & 1 & $1.409 \mathrm{E}+05$ & $1.409 \mathrm{E}+05$ & 69.88 & $0.0,001$ & $\bar{Y}$ & 36.0 \\
\hline & HRWRA & 1 & $2.475 \mathrm{E}+05$ & $2.475 \mathrm{E}+05$ & 122.73 & 0.0001 & $\mathrm{Y}$ & 63.2 \\
\hline & B & 1 & 3101.39 & 3101.39 & 1.54 & 0.2432 & $\mathrm{~N}$ & 0.8 \\
\hline \multirow[t]{3}{*}{ V-funnel } & $\mathrm{w} / \mathrm{b}$ & 1 & 571.98 & 571.98 & 192.66 & 0.0001 & $\mathrm{Y}$ & 92.3 \\
\hline & HRWRA & 1 & 46.72 & 46.72 & 15.74 & 0.0027 & $\mathrm{Y}$ & 7.5 \\
\hline & $\mathrm{B}$ & 1 & 1.09 & 1.09 & 0.37 & 0.5574 & $\mathrm{~N}$ & 0.2 \\
\hline \multirow[t]{3}{*}{ J-ring flow } & $\mathrm{w} / \mathrm{b}$ & 1 & $1.302 \mathrm{E}+05$ & $1.302 \mathrm{E}+05$ & 82.89 & 0.0001 & $\mathrm{Y}$ & 36.4 \\
\hline & HRWRA & 1 & $2.277 \mathrm{E}+05$ & $2.277 \mathrm{E}+05$ & 144.89 & 0.0001 & $\mathrm{Y}$ & 63.6 \\
\hline & B & 1 & 283.95 & 283.95 & 0.18 & 0.6798 & $\mathrm{~N}$ & 0.1 \\
\hline \multirow[t]{3}{*}{ J-ring height } & $\mathrm{w} / \mathrm{b}$ & 1 & 70.55 & 70.55 & 45.19 & 0.0001 & $\mathrm{Y}$ & 38.6 \\
\hline & HRWRA & 1 & 103.91 & 103.91 & 66.55 & 0.0001 & $\mathrm{Y}$ & 56.9 \\
\hline & B & 1 & 8.28 & 8.28 & 5.30 & 0.0441 & $\mathrm{Y}$ & 4.5 \\
\hline \multirow[t]{3}{*}{ L-box } & $\mathrm{w} / \mathrm{b}$ & 1 & 0.34 & 0.34 & 35.61 & 0.0001 & $\mathrm{Y}$ & 37.5 \\
\hline & HRWRA & 1 & 0.56 & 0.56 & 58.53 & 0.0001 & $\mathrm{Y}$ & 61.6 \\
\hline & $\mathrm{B}$ & 1 & $7.722 \mathrm{E}-03$ & $7.722 \mathrm{E}-03$ & 0.81 & 0.3896 & $\mathrm{~N}$ & 0.9 \\
\hline \multirow[t]{3}{*}{ Filling capacity } & $\mathrm{w} / \mathrm{b}$ & 1 & 3663.64 & 3663.64 & 53.31 & 0.0001 & $\mathrm{Y}$ & 37.7 \\
\hline & HRWRA & 1 & 5964.65 & 5964.65 & 86.79 & 0.0001 & $\mathrm{Y}$ & 61.4 \\
\hline & $\mathrm{B}$ & 1 & 87.97 & 87.97 & 1.28 & 0.2843 & $\mathrm{~N}$ & 0.9 \\
\hline \multirow{3}{*}{$\begin{array}{c}\text { Sieve } \\
\text { segregation } \\
\text { resistance }\end{array}$} & $\mathrm{w} / \mathrm{b}$ & 1 & 464.58 & 464.58 & 31.88 & 0.0001 & $\mathrm{Y}$ & 29.9 \\
\hline & HRWRA & 1 & 357.16 & 357.16 & 24.51 & 0.0003 & $\mathrm{Y}$ & 22.9 \\
\hline & B & 1 & 734.64 & 7.34 .64 & 50.41 & 0.0001 & $\mathrm{Y}$ & 47.2 \\
\hline \multirow{3}{*}{\begin{tabular}{c|} 
7-Day \\
compressive \\
strength
\end{tabular}} & $\mathrm{w} / \mathrm{b}$ & 1 & 357.62 & 357.62 & 82.24 & 0.0001 & $\mathrm{Y}$ & 69.3 \\
\hline & HRWRA & 1 & 28.85 & 28.85 & 6.63 & 0.0203 & $\mathrm{Y}$ & 5.6 \\
\hline & B & 1 & 129.55 & 129.55 & 29.79 & 0.0001 & $\mathrm{Y}$ & 25.1 \\
\hline \multirow{3}{*}{$\begin{array}{c}\text { 28-Day } \\
\text { compressive } \\
\text { strength }\end{array}$} & $\mathrm{w} / \mathrm{b}$ & 1 & 637.51 & 637.51 & 84.72 & 0.0001 & $\mathrm{Y}$ & 69.0 \\
\hline & HRWRA & 1 & 41.52 & 41.52 & 5.52 & 0.0407 & $\mathrm{Y}$ & 4.5 \\
\hline & $\mathrm{B}$ & 1 & 244.55 & 244.55 & 32.50 & 0.0002 & $\mathrm{Y}$ & 26.5 \\
\hline \multirow{3}{*}{$\begin{array}{c}\text { Fresh unit } \\
\text { weight }\end{array}$} & $\mathrm{w} / \mathrm{b}$ & 1 & 622.78 & 622.78 & 0.70 & 0.4212 & $\mathrm{~N}$ & 7.4 \\
\hline & HRWRA & 1 & 683.54 & 683.54 & 0.77 & 0.4001 & $\mathrm{~N}$ & 8.1 \\
\hline & $\mathrm{B}$ & 1 & 7092.69 & 7092.69 & 8.01 & 0.0178 & $\mathrm{Y}$ & 84.5 \\
\hline \multirow{3}{*}{$\begin{array}{c}\text { 28-Day air dry } \\
\text { unit weight }\end{array}$} & $\mathrm{w} / \mathrm{b}$ & 1 & 75.35 & 75.35 & 0.061 & 0.8093 & $\mathrm{~N}$ & 0.9 \\
\hline & HRWRA & 1 & 733.33 & 733.33 & 0.59 & 0.4561 & $\mathrm{~N}$ & 8.3 \\
\hline & B & 1 & 8057.00 & 8057.00 & 6.48 & 0.0244 & $\mathrm{Y}$ & 90.9 \\
\hline \multirow{3}{*}{$\begin{array}{c}\text { 28-Day oven } \\
\text { dry unit } \\
\text { weight }\end{array}$} & $\mathrm{w} / \mathrm{b}$ & 1 & 546.73 & 546.73 & 0.53 & 0.4852 & $\mathrm{~N}$ & 6.6 \\
\hline & HRWRA & 1 & 784.87 & 784.87 & 0.75 & 0.4055 & $\mathrm{~N}$ & 9.4 \\
\hline & B & 1 & 6989.34 & 6989.34 & 6.72 & 0.0269 & $\mathrm{Y}$ & 84.0 \\
\hline
\end{tabular}

DOF degree of freedom, $F$ statistic test, $p$ value probabilities.

Significant: $p<0.050$ ( $Y$ yes $), p>0.050$ ( $N$ no). 
Table 7 Mathematical formulation of ESH-LWSCC properties.

\begin{tabular}{|c|c|c|c|c|c|c|c|}
\hline Parameters & Slump flow & V-funnel & J-ring flow & J-ring height & L-box & Filling capacity & SSR \\
\hline Constant & -2631.74 & 282.93946 & -2803.42 & 130.55 & -10.61 & -1020.89 & -183.568 \\
\hline $\mathrm{w} / \mathrm{b}$ & 14376.546 & -1391.542 & 13859.24 & -479.9 & 48.58 & 4597.46 & 632.705 \\
\hline HRWRA & 356.7146 & -32.51110 & 387.503 & -51.01 & 0.77 & 136.18 & 38.001 \\
\hline B & 0.95820 & $5.826 \mathrm{E}-03$ & 1.788 & 0.051 & $8.8 \mathrm{E}-03$ & 0.800 & 0.3084 \\
\hline $\mathrm{w} / \mathrm{b} \times \mathrm{HRWRA}$ & 416.66667 & 59.47019 & 333.333 & 55.55 & 1.16 & 7.820 & 8.2980 \\
\hline $\mathrm{w} / \mathrm{b} \times \mathrm{B}$ & 1.25000 & -0.13444 & 1.428 & 0.142 & $-1.8 \mathrm{E}-3$ & -0.203 & -1.070 \\
\hline HRWRA $\times$ B & 0.29762 & $9.043 \mathrm{E}-03$ & 0.39683 & 0.023 & $7.3 \mathrm{E}-04$ & 0.0455 & -0.060 \\
\hline$(w / b)^{2}$ & -18735.07 & 1818.468 & -18149.1 & 458.64 & -64.59 & -5369.08 & - \\
\hline (HRWRA) $^{2}$ & -217.9190 & 1.98610 & -259.424 & 9.077 & -0.7061 & -74.20 & - \\
\hline$(B)^{2}$ & $-1.925 \mathrm{E}-3$ & $4.035 \mathrm{E}-05$ & $-2.6 \mathrm{E}-03$ & $-2.8 \mathrm{E}-5$ & $-9.5 \mathrm{E}-6$ & $-8.35 \mathrm{E}-4$ & - \\
\hline$R^{2}$ & 0.96 & 0.97 & 0.96 & 0.94 & 0.94 & 0.95 & 0.90 \\
\hline Parameters & & Comp strens & & Fresh unit & $28-\mathrm{d}$ & & 28-day oven \\
\hline & & & 28-day & weight & dry v & & dry weight \\
\hline Constant & & & -79.42 & 1697.63 & -1 & & 1995.35 \\
\hline $\mathrm{w} / \mathrm{b}$ & & & 319.19 & 973.54 & 368 & & 2279.59 \\
\hline HRWRA & & & 3.38 & 527.89 & 72 & & 563.21 \\
\hline B & & & 0.328 & -1.430 & 2. & & -4.42 \\
\hline $\mathrm{w} / \mathrm{b} \times \mathrm{HRWI}$ & & & -1.038 & -915.71 & -11 & 45 & -1082.20 \\
\hline $\mathrm{w} / \mathrm{b} \times \mathrm{B}$ & & & 0.229 & -5.35 & -5 & & -4.81 \\
\hline HRWRA $\times$ & & & $-1.9 \mathrm{E}-3$ & -0.579 & -0 & & -0.52 \\
\hline$(\mathrm{w} / \mathrm{b})^{2}$ & & & -821.05 & 3053.463 & & & 1012.11 \\
\hline$\overline{(\text { HRWRA) }}$ & & & -4.14 & 58.42 & & & 55.48 \\
\hline$(B)^{2}$ & & & $-3.6 \mathrm{E}-4$ & $4.25 \mathrm{E}-03$ & & & $7.12 \mathrm{E}-03$ \\
\hline$R^{2}$ & & & 0.93 & 0.73 & & & 0.75 \\
\hline
\end{tabular}

When determining the model for each response, a regression analysis is performed on the basis of a partial model containing only the terms which are statistically significant at a 0.05 level of significance. Then, t-statistics are calculated and the terms that are statistically insignificant are eliminated. This process is repeated until the partial model contains only the significant terms. The experimental data are fed to a mathematical model through multiple linear regression analysis which consisted of the terms which are statistically significant at a 0.05 level. $R^{2}$ statistic, which gives a correlation between the experimental data and the predicted response, should be high enough for a particular model to be significant (Muthukumar and Mohan 2004).

The derived equations of the modelled responses are summarized in Table 7 for ESH-LWSCC mixtures. In this Table, mixture variables expressed in actual factored values present a comparison of various parameters as well as the interactions of the modelled responses. The model constants are determined by multi-regression analysis and are assumed to be normally distributed. A negative estimate signifies that an increase of the given parameter results in a reduction of the measured response. For any given response, the presence of parameters with coupled terms, such as $(w / b)^{2}$ and $(w / b)^{3}$ indicates that the influence of this parameter $(w / b)$ is quadratic and cubic, respectively.

\subsection{Repeatability of the Test Parameters}

The repeatability of test parameters at central points is given in Table 8. ESH-LWSCC mixtures 15-20 (center point mixes) are found to satisfy LWSCC performance criteria. This table shows the mean results, standard deviation and coefficient of variance (COV), as well as the standard errors and the relative errors, with $95 \%$ confidence limit of measured response of the six repeated mixes. The relative errors at the $95 \%$ confidence limit for slump flow, V-funnel flow time, J-ring flow, L-box, filling capacity, sieve segregation resistance test, fresh unit weight, 28-day air dry unit weight, 28-day oven dry unit weight, and 7- and 28-day compressive strength in ESH-LWSCC model are found to be limited to $0.6-9.7 \%$. On the other hand, the relative error 
Table 8 Repeatability of test parameters for ESH-LWSCC mixtures.

\begin{tabular}{|c|c|c|c|c|c|}
\hline Test method & Mean $(n=6)$ & $\mathrm{SD}$ & $\operatorname{COV}(\%)$ & $\begin{array}{l}\text { Estimated error } \\
\quad(95 \% \mathrm{CI})\end{array}$ & Relative error $(\%)$ \\
\hline Slump flow (mm) & 692.50 & 12.55 & 1.8 & 12.26 & 1.8 \\
\hline V-funnel (s) & 3.77 & 0.23 & 6.2 & 0.23 & 6.1 \\
\hline J-ring flow (mm) & 691.67 & 13.29 & 1.9 & 12.99 & 1.9 \\
\hline J-ring height $(\mathrm{mm})$ & 1.50 & 0.55 & 36.5 & 0.54 & 35.7 \\
\hline L-box (ratio) & 0.99 & 0.01 & 1.3 & 0.01 & 1.2 \\
\hline Filling capacity (\%) & 98.33 & 1.21 & 1.2 & 1.18 & 1.2 \\
\hline $\begin{array}{l}\text { Sieve segregation } \\
\text { resistance }(\%)\end{array}$ & 11.83 & 1.17 & 9.9 & 1.14 & 9.7 \\
\hline $\begin{array}{c}\text { 7-Day comp strength } \\
(\mathrm{MPa})\end{array}$ & 32.00 & 1.26 & 4.0 & 1.24 & 3.9 \\
\hline $\begin{array}{c}\text { 28-Day comp strength } \\
(\mathrm{MPa})\end{array}$ & 45.00 & 1.79 & 4.0 & 1.75 & 3.9 \\
\hline $\begin{array}{l}\text { Fresh unit weight } \\
\qquad\left(\mathrm{kg} / \mathrm{m}^{3}\right)\end{array}$ & 1790.67 & 10.78 & 0.6 & 10.54 & 0.6 \\
\hline $\begin{array}{c}\text { 28-Day air dry unit } \\
\left(\mathrm{kg} / \mathrm{m}^{3}\right)\end{array}$ & 1674.17 & 11.44 & 0.7 & 11.18 & 0.7 \\
\hline $\begin{array}{l}\text { 28-Day oven dry unit } \\
\qquad\left(\mathrm{kg} / \mathrm{m}^{3}\right)\end{array}$ & 1614.33 & 13.85 & 0.9 & 13.53 & 0.8 \\
\hline
\end{tabular}

for J-ring height difference is found $35.7 \%$. The relative error was defined as the value of the error with $95 \%$ confidence limit divided by the mean value.

\section{Phase III: Optimization-Validation of the Statistical Models and Development of Industrial ESH-LWSCC}

This phase included the validation of the statistical model and mix proportion optimization process. The optimization was performed to develop mixtures that satisfy EFNARC industrial classifications for SCC (EFNARC 2005). Moreover, this phase also presents the results of additional experimental study to validate whether the theoretically proposed optimum mix design parameters such as $\mathrm{w} / \mathrm{b}$, HRWRA\%, and total binder (B) can yield the desired fresh and hardened properties for ESH-LWSCCs.

\subsection{Verification of Statistical Models}

The accuracy of the proposed model was determined by comparing predicted-to-measured values obtained with mixes prepared at the centre of the experimental domain and five other random mixes. Mixes 1-5 were randomly selected to cover a wide range of mixture proportioning within the modelled region, while mixes 6-10 were the centre points of the models. Mixture proportioning and measured responses of these ESH-LWSCC mixtures are presented in Tables 9 and 10 , respectively.
Comparisons between predicted and measured values for various ESH-LWSCC responses are illustrated in Figs. 9 and 10 where the dashed lines present the upper and lower estimated error at $95 \%$ confidence limit. Points found above the 1:1 diagonal line indicates that the statistical model overestimates the measured response.

On average, the predicated-to-measured ratios of slump flow, J-Ring flow, L-box ratio, V-funnel flow time, J-Ring height difference, filling capacity $\%$, SSR index $\%$, fresh unit weight, 28-day air-dry unit weight, 28-day oven dry unit weight, and 7- and 28-day compressive strengths were 1.02, $1.01,1.0,0.99,0.98,1.02,1.02,1.0,1.0,1.0,1.02$ and 1.02, respectively, indicating an accurate prediction of measured responses within the modelled region. The majority of the data for the measured responses lie close to the 1:1 diagonal line, resulting in the mean value of ratio between predicatedto-measured responses to be $1.00 \pm 0.02$. This indicates a high accuracy of the derived model to predicate the response.

On the other hand, the majority of the predicated slump flow, J-Ring flow, L- box ratio, V-funnel flow time, J-ring height difference, filling capacity, SSR index, fresh unit weight, 28-day air-dry unit weight, 28-day oven dry unit weight, and 7- and 28-day compressive strengths values (Figs. 9, 10) are within the acceptable limit of \pm 12.26 , $\pm 12.99 \mathrm{~mm}, \pm 0.01, \pm 0.23 \mathrm{~s}, \pm 0.54 \mathrm{~mm}, \pm 1.18, \pm 1.14 \%$, $\pm 10.54, \pm 11.18, \pm 13.53 \mathrm{~kg} / \mathrm{m}^{3}, \pm 1.24$ and $\pm 1.75 \mathrm{MPa}$, respectively. These limits constitute experimental errors for responses determined from the repeatability tests. 
Table 9 Mixture proportions for ESH-LWSCC.

\begin{tabular}{c|c|c|c|c|c|c|c|c|c|c}
\hline Mix no. & $\begin{array}{c}\text { X1 } \\
(\mathrm{w} / \mathrm{b})\end{array}$ & $\begin{array}{c}\text { X2 } \\
(\text { HRWRA })\end{array}$ & $\begin{array}{c}\text { X3 } \\
(\mathrm{B})\end{array}$ & $\begin{array}{c}\text { Cement } \\
\left(\mathrm{kg} / \mathrm{m}^{3}\right)\end{array}$ & $\begin{array}{c}\text { FA } \\
\left(\mathrm{kg} / \mathrm{m}^{3}\right)\end{array}$ & $\begin{array}{c}\text { SF } \\
\left(\mathrm{kg} / \mathrm{m}^{3}\right)\end{array}$ & $\begin{array}{c}\text { HRWRA } \\
\left(1 / \mathrm{m}^{3}\right)\end{array}$ & \multicolumn{2}{|c|}{$\begin{array}{c}\text { Water } \\
\left(1 / \mathrm{m}^{3}\right)\end{array}$} & $\begin{array}{c}\text { ESH-aggregate }\left(\mathrm{kg} / \mathrm{m}^{3}\right) \\
\text { Coarse }\end{array}$ \\
\hline \hline ESH1 & 0.4 & 0.60 & 520 & 416 & 65 & 39 & 2.9 & 208 & 400 & 640 \\
\hline ESH2 & 0.36 & 0.88 & 430 & 344 & 54 & 32 & 3.6 & 155 & 455 & 733 \\
\hline ESH3 & 0.32 & 0.94 & 550 & 440 & 69 & 41 & 4.9 & 176 & 415 & 665 \\
\hline ESH4 & 0.37 & 0.30 & 420 & 336 & 53 & 32 & 1.2 & 155 & 462 & 738 \\
\hline ESH5 & 0.33 & 1.00 & 450 & 360 & 56 & 34 & 4.2 & 148 & 455 & 730 \\
\hline ESH6 & 0.35 & 0.75 & 480 & 384 & 60 & 36 & 3.6 & 168 & 438 & 698 \\
\hline ESH7 & 0.35 & 0.75 & 480 & 384 & 60 & 36 & 3.6 & 168 & 438 & 698 \\
\hline ESH8 & 0.35 & 0.75 & 480 & 384 & 60 & 36 & 3.6 & 168 & 438 & 698 \\
\hline ESH9 & 0.35 & 0.75 & 480 & 384 & 60 & 36 & 3.6 & 168 & 438 & 698 \\
\hline ESH10 & 0.35 & 0.75 & 480 & 384 & 60 & 36 & 3.6 & 168 & 438 & 698 \\
\hline
\end{tabular}

Table 10 Test results of ESH-LWSCC mixes used to validate statistical models.

\begin{tabular}{|c|c|c|c|c|c|c|c|c|}
\hline Mix no. & Slump flow $(\mathrm{mm})$ & V-funnel (s) & $\begin{array}{c}\text { J-ring Flow } \\
(\mathrm{mm})\end{array}$ & $\begin{array}{l}\text { J-ring height } \\
\text { diff }(\mathrm{mm})\end{array}$ & L-box ratio & \multicolumn{2}{|c|}{$\begin{array}{c}\text { Filling capacity } \\
(\%)\end{array}$} & SSR (\%) \\
\hline ESH1 & 688 & 1.6 & 698 & 0.5 & 0.86 & \multicolumn{2}{|l|}{88} & 13 \\
\hline $\mathrm{ESH} 2$ & 715 & 2.6 & 698 & 1.5 & 1.00 & \multicolumn{2}{|l|}{100} & 22 \\
\hline ESH3 & 636 & 9.4 & 655 & 1.0 & 0.82 & \multicolumn{2}{|l|}{82} & 7 \\
\hline ESH4 & 562 & 3.7 & 542 & 5.5 & 0.69 & \multicolumn{2}{|l|}{68} & 19 \\
\hline ESH5 & 708 & 5.8 & 695 & 1.5 & 0.95 & \multicolumn{2}{|l|}{96} & 19 \\
\hline ESH6 & 705 & 3.7 & 710 & 2.0 & 0.98 & \multicolumn{2}{|l|}{100} & 11 \\
\hline ESH7 & 685 & 4.0 & 680 & 1.0 & 1.00 & \multicolumn{2}{|l|}{99} & 12 \\
\hline ESH8 & 700 & 3.7 & 700 & 1.0 & 0.97 & \multicolumn{2}{|l|}{97} & 13 \\
\hline ESH9 & 685 & 3.5 & 680 & 1.0 & 1.00 & \multicolumn{2}{|l|}{97} & 10 \\
\hline ESH10 & 705 & 4.1 & 700 & 2.0 & 0.99 & \multicolumn{2}{|l|}{99} & 12 \\
\hline \multirow[t]{2}{*}{ Mix no. } & \multicolumn{3}{|c|}{ Comp strength } & \multicolumn{5}{|c|}{ Unit weight $\left(\mathrm{kg} / \mathrm{m}^{3}\right)$} \\
\hline & \multicolumn{2}{|c|}{ 7-Day } & 28-Day & Fresh & \multicolumn{2}{|c|}{ 28-Day air dry } & & -Day oven dry \\
\hline ESH1 & \multicolumn{2}{|c|}{27} & 38 & 1,806 & \multicolumn{2}{|c|}{1,702} & & 1,630 \\
\hline $\mathrm{ESH} 2$ & \multicolumn{2}{|c|}{27} & 39 & 1,781 & \multicolumn{2}{|c|}{1,675} & & 1,611 \\
\hline ESH3 & 3 & 6 & 50 & 1,853 & & 733 & & 1,688 \\
\hline ESH4 & 2 & 7 & 37 & 1,782 & & 662 & & 1,616 \\
\hline ESH5 & 3 & 0 & 44 & 1,797 & & 692 & & 1,622 \\
\hline ESH6 & 3 & 4 & 48 & 1,789 & & 676 & & 1,604 \\
\hline ESH7 & 3 & 2 & 44 & 1,779 & & 667 & & 1,611 \\
\hline ESH8 & 3 & 1 & 45 & 1,782 & & 670 & & 1,614 \\
\hline ESH9 & 3 & 3 & 46 & 1,787 & & 662 & & 1,597 \\
\hline ESH10 & 3 & 1 & 43 & 1,800 & & 675 & & 1,625 \\
\hline
\end{tabular}

As can be seen from the validation investigation, the derived model offers adequate predication of workability, unit weight and compressive strength response within the experimental domain of the modelled mixture parameters. It is important to note that the absolute values of the predicated values are expected to change with the changes in raw 

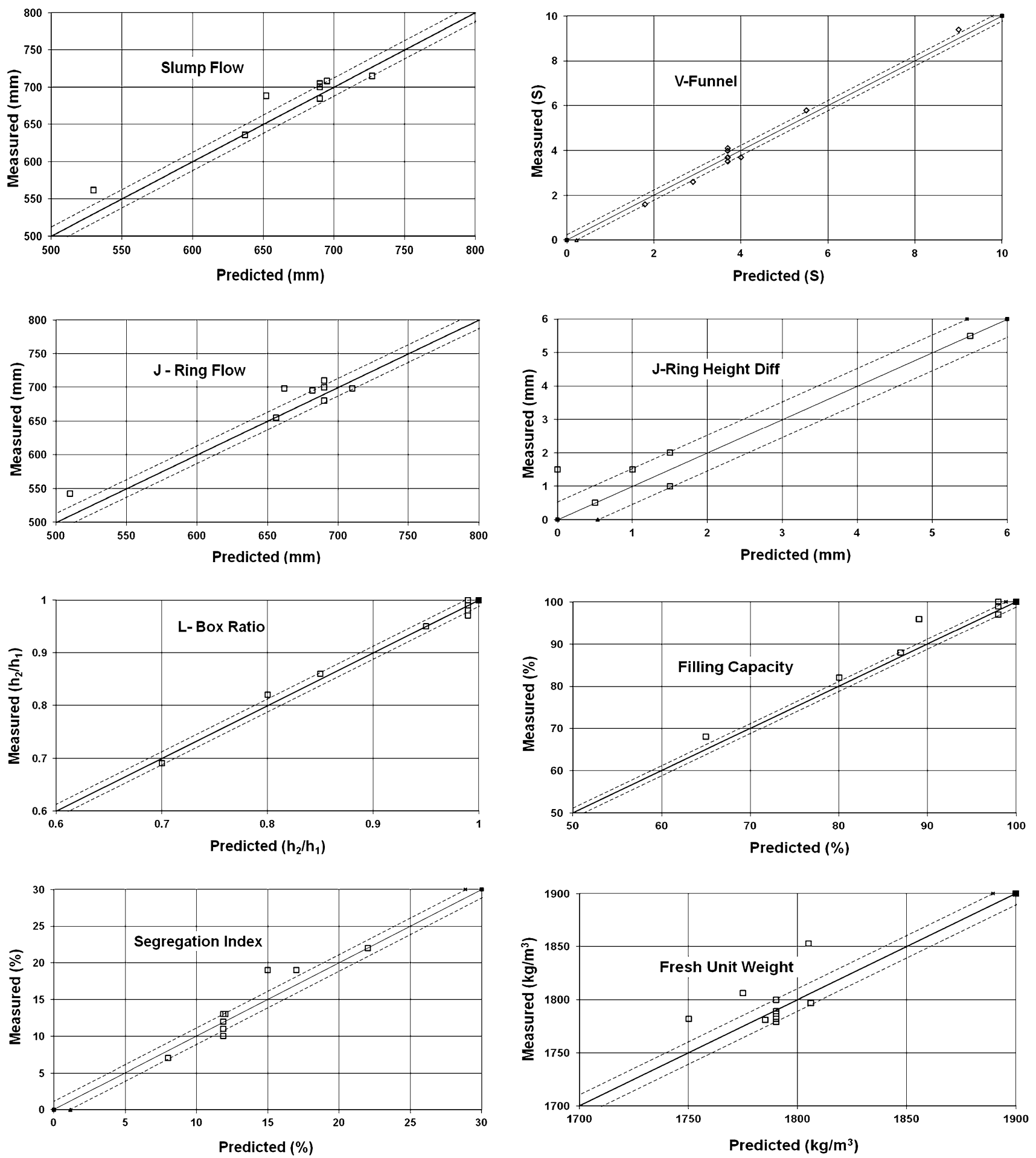

Fig. 9 Predicted versus measured fresh state properties of ESH-LWSCC.

material characteristics. However, the relative contributions of the various parameters are expected to be the same, thus facilitating the mix design protocol.

\subsection{ESH-LWSCC Mixture Optimization}

Based on the developed statistical model and the outlined relationships between mix design variables and the responses as shown in Table 9, all independent variables are varied simultaneously and independently in order to optimize the response. The objective of the optimization process is to obtain the "best fit" for particular response, considering alternating multiple responses concurrently. In this study, optimization was performed to develop mixtures that satisfy EFNARC industrial classifications for SCC (EFNARC 2005). The fresh properties of SCC as per EFNARC are presented in Table 11.

The mix proportions (independent variables) were optimized to yield three ESH-LWSCC mixtures with the following fresh properties/classes:

(1) $\mathrm{SF} 1+\mathrm{VF} 1+\mathrm{PA} 2+\mathrm{SR} 2$ (Casting by a pump injection system e.g. tunnel linings): ESH-LWSCC1 

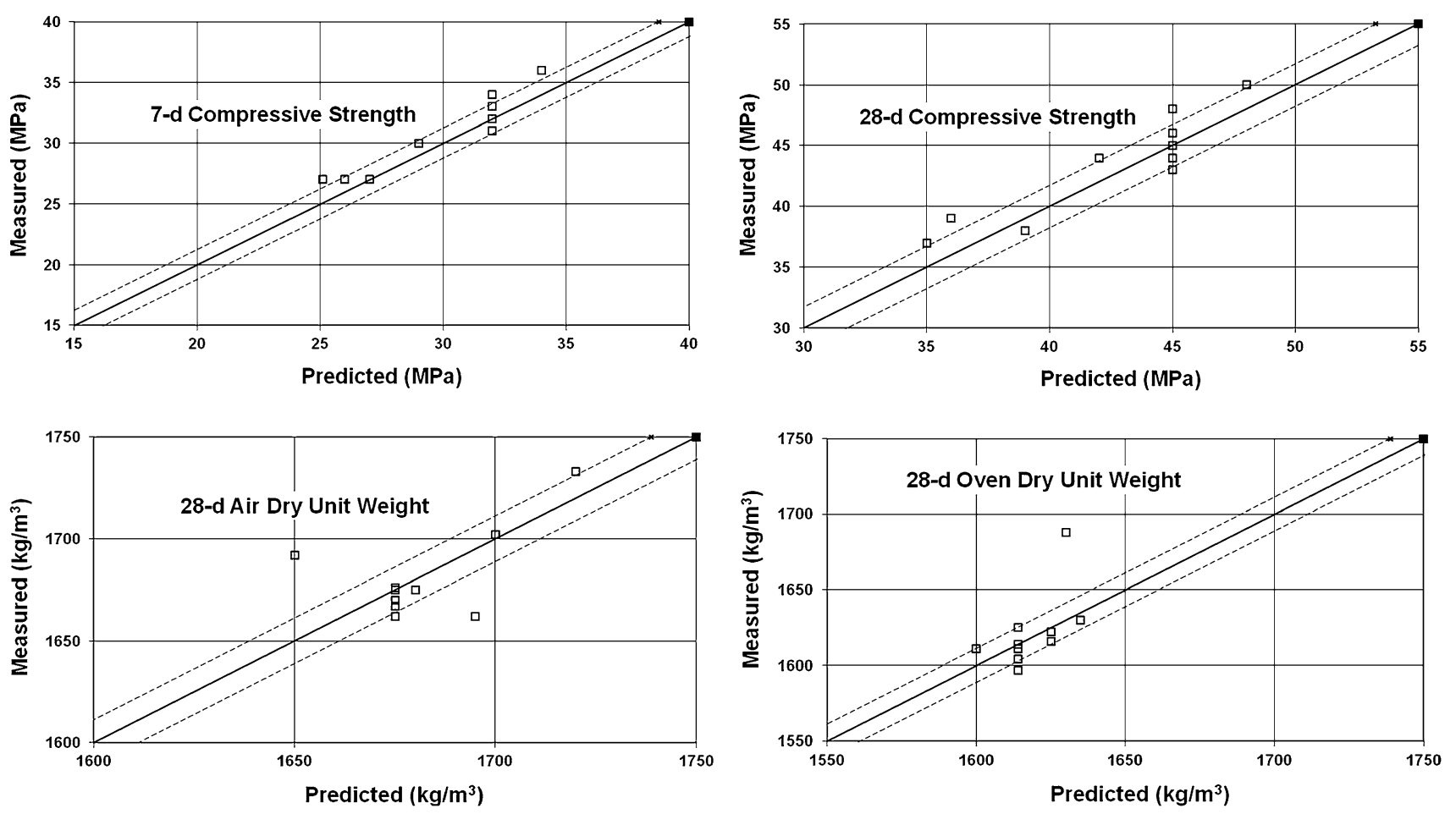

Fig. 10 Predicted versus measured hardened properties of ESH-LWSCC.

Table 11 EFNARC SCC classification.

\begin{tabular}{|c|c|c|c|}
\hline Slum & & \multicolumn{2}{|c|}{ Slump flow (mm) } \\
\hline \multicolumn{2}{|c|}{$\mathrm{SF} 1$} & \multicolumn{2}{|c|}{$550-650$} \\
\hline \multicolumn{2}{|c|}{ SF2 } & \multicolumn{2}{|c|}{$660-750$} \\
\hline \multicolumn{2}{|c|}{ SF3 } & \multicolumn{2}{|c|}{$760-850$} \\
\hline Viscosity & \multicolumn{2}{|c|}{$\mathrm{T} 500(\mathrm{~s})$} & V-funnel (s) \\
\hline VS1/VF1 & \multicolumn{2}{|c|}{$\leq 2$} & $\leq 8$ \\
\hline $\mathrm{VS} 2 / \mathrm{V} 2$ & \multicolumn{2}{|c|}{$>2$} & $9-25$ \\
\hline Passing $a b$ & & \multicolumn{2}{|c|}{ Passing ability ratio $\left(h_{2} / h_{1}\right)$} \\
\hline \multicolumn{2}{|c|}{ PA1 } & \multicolumn{2}{|c|}{$\geq 0.80$ with two rebars } \\
\hline \multicolumn{2}{|c|}{ PA2 } & \multicolumn{2}{|c|}{$\geq 0.80$ with three rebars } \\
\hline \multicolumn{2}{|c|}{ Sieve segregation resistance } & \multicolumn{2}{|c|}{ Segregation resistance (\%) } \\
\hline \multicolumn{2}{|c|}{ SR1 } & \multicolumn{2}{|c|}{$\leq 20$} \\
\hline \multicolumn{2}{|c|}{ SR1 } & \multicolumn{2}{|c|}{$\leq 15$} \\
\hline
\end{tabular}

(2) $\mathrm{SF} 2+\mathrm{VF} 1+\mathrm{PA} 2+\mathrm{SR} 2$ (Suitable for many normal applications e.g. walls, columns): ESH-LWSCC2

(3) $\mathrm{SF} 3+\mathrm{VF} 1+\mathrm{PA} 2+\mathrm{SR} 1$ (Suitable for vertical applications in very congested structures, structures with complex shapes, or for filling under formwork): ESHLWSCC 3

VF1 limits were constrained tighter as $4-8 \mathrm{~s}$ for ESHLWSCC 1 and 2 to ensure density stability during application and placement. A numerical optimization technique, using desirability functions $\left(d_{j}\right)$ defined for each target response, was utilized to optimize the responses (Whitcomb and Anderson 2004; Pradeep 2008; Ozbay et al. 2011). Desirability is an objective function that ranges from 0 to 1 , where 0 indicates it is outside the range and 1 indicates the goal is fully achieved. The numerical optimization finds a point that maximizes the desirability function. The characteristics of a goal may be altered by adjusting the weight or importance (Ozbay et al. 2011). In this research, target responses were assigned equal weight and importance. All target responses were combined into a desirability function and the numerical optimization software was used to maximize this function (Ozbay et al. 2011; Nehdi and Summer 2002). The goals seeking begin at a random starting point and proceeds up the steepest slope to a maximum. To perform the optimization process, goals, upper and lower limits for the factors and responses were defined as in Table 12.

In order to have an equal importance, five predefined responses (slump flow, J-ring flow, V- funnel, L-box and SSR index) in addition to the goal to minimize both J- ring height difference and fresh unit weight response were considered and optimized simultaneously. Furthermore, filling capacity, 28-day air dry unit weight, 28-day oven dry unit weight, and 7- and 28-day compressive strengths were defined as in the experimental study range.

After runing the numerical optimization process for ESHLWSCC-1 mixture, 29 solutions were obtained, satisfying the set limits and constrains. The desirability of the proposed solutions ranged from 0.732 to 0.810 . As for ESH-LWSCC2 and 3 mixtures, 25 and 30 solutions were obtained, with desirability ranging from 0.798 to 0.864 and 0.800 to 0.908 , respectively. The highest desirability functions value 0.810 , 0.864 and 0.908 for achieving the set, goals and limits are given in Table 12. The desirability function changed based 
Table 12 Classification of responses goal and limits.

\begin{tabular}{|c|c|c|c|c|c|c|c|}
\hline \multirow{2}{*}{$\begin{array}{c}\text { Name of } \\
\text { responses }\end{array}$} & \multirow[t]{2}{*}{ Goal } & Lower limit & Upper limit & Lower limit & Upper limit & Lower limit & Upper limit \\
\hline & & \multicolumn{2}{|c|}{ ESH-LWSCC-1 } & \multicolumn{2}{|c|}{ ESH-LWSCC-2 } & \multicolumn{2}{|c|}{ ESH-LWSCC-3 } \\
\hline $\begin{array}{l}\text { Slump flow } \\
\text { (mm) }\end{array}$ & In range & 550 & 650 & 660 & 750 & 760 & 850 \\
\hline V-funnel (S) & In range & 4 & 8 & 4 & 8 & 0.0 & 8 \\
\hline J-ring flow $(\mathrm{mm})$ & In range & 550 & 650 & 660 & 750 & 760 & 850 \\
\hline $\begin{array}{l}\text { J-ring height } \\
(\mathrm{mm})\end{array}$ & Minimize & 0.0 & 14.0 & 0.0 & 14.0 & 0.0 & 14.0 \\
\hline $\begin{array}{l}\text { L-box ratio } \\
\qquad\left(\mathrm{h}_{2} / \mathrm{h}_{1}\right)\end{array}$ & In range & 0.8 & 1.0 & 0.8 & 1.0 & 0.8 & 1.0 \\
\hline $\begin{array}{c}\text { Filling capacity } \\
(\%)\end{array}$ & In range & 80 & 100 & 80 & 100 & 80 & 100 \\
\hline $\begin{array}{c}\text { Sieve segregation } \\
(\%)\end{array}$ & In range & 0.0 & 15 & 0.0 & 15 & 0.0 & 20 \\
\hline $\begin{array}{l}\text { 7-Day comp } \\
\text { strength }(\mathrm{MPa})\end{array}$ & In range & 20 & 40 & 20 & 40 & 20 & 40 \\
\hline $\begin{array}{l}\text { 28-Day comp } \\
\text { strength }(\mathrm{MPa})\end{array}$ & In range & 28 & 53 & 28 & 53 & 28 & 53 \\
\hline $\begin{array}{c}\text { Fresh unit weight } \\
(\mathrm{MPa})\end{array}$ & Minimize & 1,742 & 1,892 & 1,742 & 1,892 & 1,742 & 1,892 \\
\hline $\begin{array}{c}\text { 28-Day air dry } \\
\text { unit }\left(\mathrm{kg} / \mathrm{m}^{3}\right)\end{array}$ & In range & 1,611 & 1,765 & 1,611 & 1,765 & 1,611 & 1,765 \\
\hline $\begin{array}{c}\text { 28-Day oven dry } \\
\text { unit }\left(\mathrm{kg} / \mathrm{m}^{3}\right)\end{array}$ & In range & 1,566 & 1,729 & 1,566 & 1,729 & 1,566 & 1,729 \\
\hline
\end{tabular}

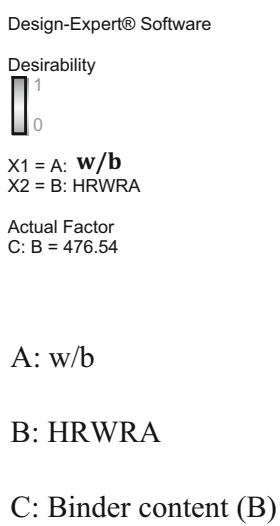

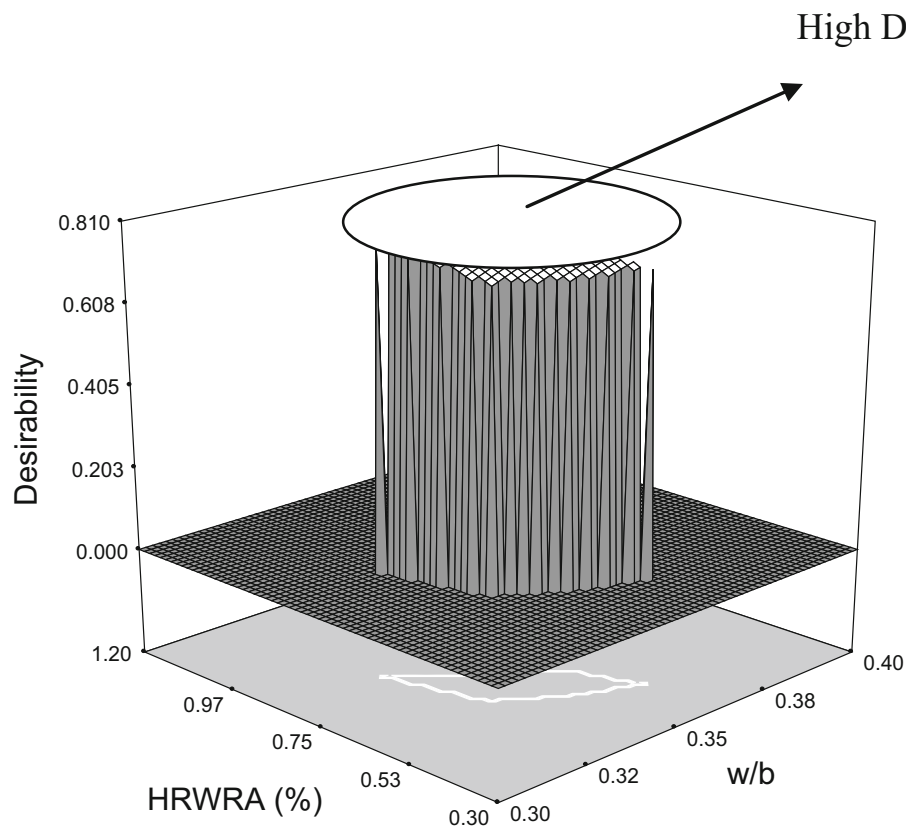

Fig. 11 Effect of w/b, HRWRA and total binder content at $476 \mathrm{~kg} / \mathrm{m}^{3}$ on the desirability function of ESH-LWSCC-1 mixture (EFNARC SCC class 1 ).

on the optimization process and is graphically presented in Figs. 11 and 12. For ESH-LWSCC mixes of classes 1 and 2 (when keeping the binder content constant at $476,486 \mathrm{~kg} /$ $\mathrm{m}^{3}$, respectively), it was found that the desirability function increased only for very limited area (highlighted in the figures), and when the w/b and HRWRA\% are between certain 
A: w/b

B: HRWRA

C: Binder content (B)

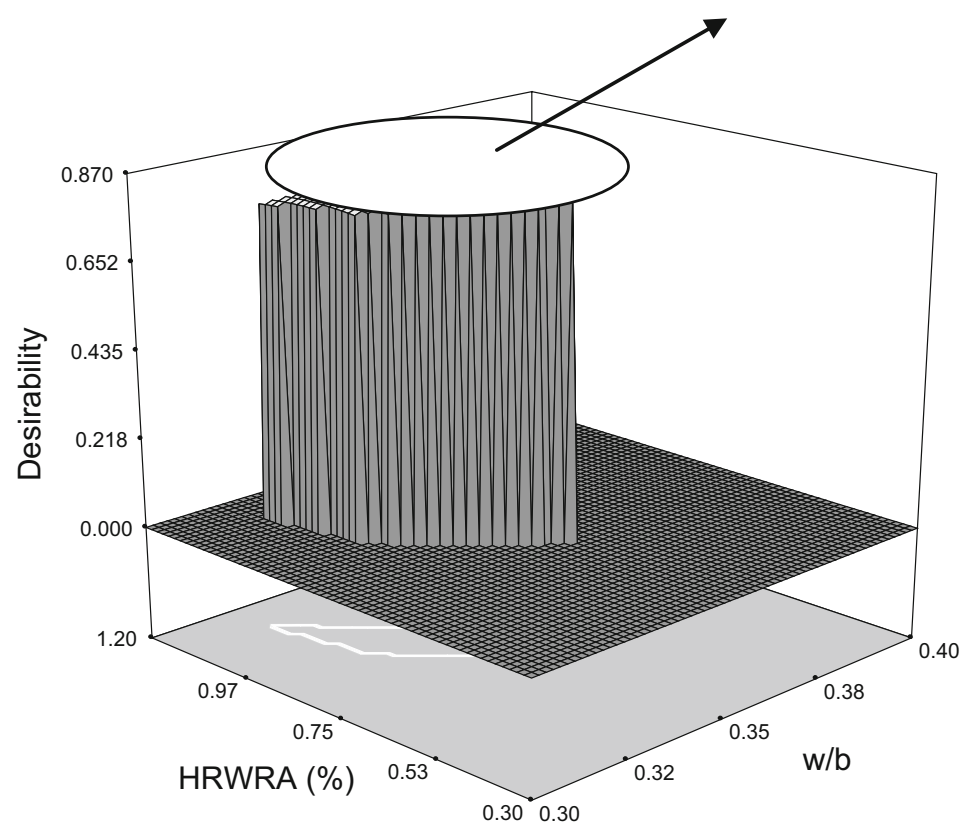

Fig. 12 Effect of w/b, HRWRA and total binder content at $486 \mathrm{~kg} / \mathrm{m}^{3}$ on the desirability function of ESH-LWSCC-2 mixture (EFNARC SCC class 2).

Table 13 Theoretically optimum mix proportions and experimental results.

\begin{tabular}{|c|c|c|c|c|c|c|}
\hline Mix no. & \multicolumn{2}{|c|}{ ESH-LWSCC-1 } & \multicolumn{2}{|c|}{ ESH-LWSCC-2 } & \multicolumn{2}{|c|}{ ESH-LWSCC-3 } \\
\hline $\begin{array}{l}\text { Mix parameters } \\
\text { and responses }\end{array}$ & $\begin{array}{l}\text { Opt values } \\
\text { and expected } \\
\text { response }\end{array}$ & $\begin{array}{l}\text { Experimental } \\
\text { results for opt mix } \\
\text { proportions }\end{array}$ & $\begin{array}{l}\text { Opt values } \\
\text { and expected } \\
\text { response }\end{array}$ & $\begin{array}{c}\text { Experimental } \\
\text { results for opt mix } \\
\text { proportions }\end{array}$ & $\begin{array}{l}\text { Opt values } \\
\text { and expected } \\
\text { response }\end{array}$ & $\begin{array}{c}\text { Experimental } \\
\text { results for opt mix } \\
\text { proportions }\end{array}$ \\
\hline $\mathrm{w} / \mathrm{b}$ & 0.35 & 0.35 & 0.35 & 0.35 & 0.40 & 0.40 \\
\hline HRWRA & 0.61 & 0.61 & 0.83 & 0.83 & 0.78 & 0.78 \\
\hline B & 476 & 476 & 486 & 486 & 504 & 504 \\
\hline Slump flow (mm) & 650 & 645 & 708 & 725 & 760 & 770 \\
\hline V-funnel (s) & 4 & 4.9 & 4 & 3.8 & 1.32 & 2.1 \\
\hline J-ring flow (mm) & 650 & 635 & 709 & 715 & 765 & 760 \\
\hline J-ring height $(\mathrm{mm})$ & 2.2 & 2 & 0.83 & 0 & 0 & 0 \\
\hline L-box (\%) & 0.91 & 0.87 & 1 & 0.98 & 0.99 & 0.99 \\
\hline Filling capacity (\%) & 90 & 88 & 99.4 & 98 & 99.99 & 98 \\
\hline $\begin{array}{c}\text { Sieve segregation } \\
(\%)\end{array}$ & 13.1 & 12.1 & 14 & 13 & 17.75 & 18.5 \\
\hline $\begin{array}{l}\text { 7-Day comp } \\
\text { strength (MPa) }\end{array}$ & 30.2 & 32.2 & 30.6 & 33 & 25.8 & 24.5 \\
\hline $\begin{array}{l}\text { 28-Day comp } \\
\text { strength }(\mathrm{MPa})\end{array}$ & 44.6 & 45.75 & 45.4 & 47.75 & 36.95 & 35.1 \\
\hline $\begin{array}{l}\text { Fresh unit weight } \\
\qquad\left(\mathrm{kg} / \mathrm{m}^{3}\right)\end{array}$ & 1,784 & 1,810 & 1,791 & 1,763 & 1,790 & 1,780 \\
\hline $\begin{array}{l}\text { 28-Day air dry unit } \\
\left(\mathrm{kg} / \mathrm{m}^{3}\right)\end{array}$ & 1,688 & 1,653 & 1,695 & 1,708 & 1,689 & 1,650 \\
\hline $\begin{array}{l}\text { 28-Day oven dry } \\
\text { unit }\left(\mathrm{kg} / \mathrm{m}^{3}\right)\end{array}$ & 1,606 & 1,585 & 1,614 & 1,602 & 1,610 & 1,590 \\
\hline Desirability & 0.81 & - & 0.86 & - & 0.91 & - \\
\hline
\end{tabular}


values. However, desirability value decreased drastically to zero outside this limited area indicating that very specific parameter range is needed to achieve high desirability above 0.8 for ESH-LWSCC mixtures. High desirability only can be achieved for ESH-LWSCC mixes of class 3 when the w/b is kept at 0.4 and for binder content above $500 \mathrm{~kg} / \mathrm{m}^{3}$.

\subsection{Verification Experiment for an Optimum Mix Design}

Utilizing the established high statistical confidence of the developed models, an experimental study was used to validate whether the theoretically proposed optimum mix design parameters, w/b, HRWRA $\%$, and total binder could yield the desired responses. The test was carried out with the same materials and under the same testing conditions. The results are presented in Table 13. As it can be seen from the optimization/validation process, the model satisfactorily derived the three desired EFNARC-SCC industrial class mixtures. The optimized mixes satisfy the ranges for slump flow, V-funnel time, L-box ratio and segregation resistance percentage.

The derived statistical models can therefore be used as useful and reliable tools in understanding the effect of various mixture constituents and their interactions on the fresh properties of LWSCC. The analysis of the derived models enables the identification of major trends and predicts the most promising direction for future mixture optimization. This can reduce the cost, time, and effort associated with the selection of trial batches.

\section{Conclusions}

The properties of lightweight self-consolidating concrete (LWSCC), developed with expanded shale (ESH) lightweight aggregates (ESH-LWSCC) were investigated. This research included comprehensive laboratory investigations leading to the development of statistical design model for ESH-LWSCC mixtures accompanied by fresh and hardened performance evaluation of the developed ESH-LWSCC mixtures having varying water to binder ratio (w/b), high range water reducing admixture (HRWRA\%) and total binder content (B). This research involved statistical modelling, mix design development, performance evaluation of ESHLWSCCs, development/validation of statistical models and development of industrial class ESH-LWSCCs. The following conclusions were derived from the results of the comprehensive series of investigations:

1. The $w / b$ has significant influence on the overall performance of ESH-LWSCCs, including fresh and hardened properties. In terms of fresh properties, the $\mathrm{w} / \mathrm{b}$ has high influence on workability and HRWRA demand. The passing ability and filling capacity increase with the increases of $w / b$. The segregation resistance decreases with increase in w/b. ESHLWSCCs with low w/b (0.35) required high dosage of HRWRA for flowability. It is noted that ESH-
LWSCC mixtures proportioned with $\mathrm{w} / \mathrm{b}$ of less than 0.33 (regardless of HRWRA\% or the total binder content), produced unsatisfactory fresh properties, and disqualified to be a LWSCC. On the other hand a balanced LWSCC mixture with $\mathrm{w} / \mathrm{b}$ of around 0.35 made with ESH lightweight aggregates exhibited satisfactory workability, passing ability, filling capacity and segregation resistance.

2. Similar to normal weight SCC, the w/b has significant influence on the compressive strength of ESH-LWSCC mixtures - mixes with w/b of 0.35 developed higher compressive strength than those with w/b of 0.40 .

3. In terms of fresh properties, the total binder content had influence on workability and static stability (segregation resistance) of ESH-LWSCCs. For a given $\mathrm{w} / \mathrm{b}$, the HRWRA demand decreased with the increase of total binder content. On the other hand, segregation resistance increased with the increase of total binder content. In contrast, at fixed HRWRA $\%$ and $w / b$, the workability/passing ability/filling capacity decreased and segregation resistance increased with the increase of total binder content.

4. The HRWRA\% had significant influence on the workability and static stability of ESH-LWSCC mixtures. For a given w/b and total binder content, the workability/ passing ability/filling capacity increased significantly and segregation resistance decreased with the increase of HRWRA $\%$.

5. The established relation between the slump flow and the segregation index confirmed the commonly held notion that ESH-LWSCCs with less than $500 \mathrm{~mm}$ slump flow should not exhibit segregation. The chances of ESH-LWSCC segregation are very high beyond a slump flow of $750 \mathrm{~mm}$ as the segregation index tends to be more than $20 \%$. It is always desirable to keep the slump flow between 550 and $750 \mathrm{~mm}$ for a stable and homogenous ESH-LWSCC mixture.

6. Generally, use of fine and coarse ESH lightweight aggregates in mix proportioning yielded concretes with a 28-day air dry unit weight of less than 1,840 $\mathrm{kg} / \mathrm{m}^{3}$, classifying them as LWSCC.

7. From ANOVA statistical analysis, it was found that both $\mathrm{w} / \mathrm{b}$ and $(\%)$ of HRWRA had significant impact on the fresh properties of LWSCC mixtures. The total binder content had insignificant impact on the workability, passing ability and filling capacity of ESH-LWSCC mixtures with high aggregate packing density. The effect of the total binder content on the segregation resistance and compressive strength of all ESHLWSCC mixtures was classified as statistically significant.

8. The established model using the fractional factorial design approach are valid for ESH-LWSCC mixtures with $\mathrm{w} / \mathrm{b}$ ranging between 0.30 and 0.40 , total binder content between 410 and $550 \mathrm{~kg} / \mathrm{m}^{3}$ and HRWRA dosages between 0.3 and $1.2 \%$ by mass of total binder content. 
9. It was possible to produce robust ESH-LWSCC mixtures that satisfy the EFNARC criteria for SCC. Three industrial classes of ESH-LWSCC mixtures with wide range of workability performance were successfully developed. These mixtures can cover various ranges of applications, such as tunnel linings, walls, columns, vertical applications in very congested structures, and structures with complex shapes.

10. The statistical analysis and validation results of the derived statistical models indicate that this model can be used to design ESH-LWSCCs and to facilitate the protocol for optimization of ESH-LWSCCs. The theoretical optimum mix proportions can be used to derive desirable fresh properties and compressive strength of ESH-LWSCCs. The developed models and guidelines will ensure a speedy mix design process and reduce the number of trials needed to achieve LWSCC mix specifications.

Overall, this research established a technology which will guide engineers, researchers and manufacturers to develop high performance ESH-LWSCC mixtures. However, additional research is needed to validate the applicability of the model with varying gradation and shapes of aggregates.

\section{Open Access}

This article is distributed under the terms of the Creative Commons Attribution License which permits any use, distribution, and reproduction in any medium, provided the original author(s) and the source are credited.

\section{References}

ACI Committee 213R. (2003). Guide for structural lightweightaggregate concrete (p. 38). Farmington Hills, MI: American Concrete Institute.

Andiç-Çakır, Ö., \& Hızal, S. (2012). Influence of elevated temperatures on the mechanical properties and microstructure of self-consolidating lightweight aggregate concrete. Construction and Building Materials, 34, 575-583.

Assaad, J. J., \& Khayat, K. H. (2006). Effect of viscosity-enhancing admixtures on formwork pressure and thixotropy of self-consolidating concrete. ACI Materials Journal, 103(4), 280-287.

ASTM C138/C138M. (2010). Standard test method for density (unit weight), yield, and air content (gravimetric) of concrete. West Conshohocken, PA: American Society for Testing and Materials.

ASTM C39. (2011). Standard test method for compressive strength of cylindrical concrete specimens. West Conshohocken, PA: American Society for Testing and Materials.

ASTM C567. (2011). Standard test method for determining density of structural lightweight concrete. West
Conshohocken, PA: American Society for Testing and Materials.

Bogas, J. A., Gomes, A., \& Pereira, M. F. C. (2012). Selfcompacting lightweight concrete produced with expanded clay aggregate. Construction and Building Materials, 35, 1013-1022.

Bouzoubaa, N., \& Lachemi, M. (2001). Self-compacting concrete incorporating high volumes of class $\mathrm{F}$ fly ash preliminary results. Cement and Concrete Research, 31(2), 413-420.

EFNARC. (2005). The European guidelines for self compacting concrete: Specification, production and use. Cambridge, UK: The Self-Compacting Concrete European Project Group.

ESCSI. (2004). Expanded clay, shale and slate, a world of application (p. 5). Worldwide, Salt Lake City, UT, Publication No. 9349.

Fragoulis, D., Stamatakis, M. G., Chaniotakis, E., \& Columbus, G. (2003). The Utilization of clayey diatomite in the production of lightweight aggregates and concrete. Tile and Brick International, 19(6), 392-397.

Fragoulis, D., Stamatakis, M. G., Chaniotakis, E., \& Columbus, G. (2004). Characterization of lightweight aggregates produced with clayey diatomite rocks originating from Greece. Materials Characterization, 53(2-4), 307-316.

Ghezal, A., \& Khayat, K. H. (2002). Optimizing self-consolidating concrete with limestone filler by using statistical factorial design methods. ACI Materials Journal, 99(3), 264-272.

Holm, T. A. (1994). Lightweight concrete and aggregates. STP 169C: Concrete and concrete: Making materials (pp. 522-532). Philadelphia, PA: American Society for Testing and Materials.

Hossain, K. M. A. (2004). Properties of volcanic pumice based cement and lightweight concrete. Cement and Concrete Research, 34(2), 283-291.

Hwang, C. L., \& Hung, M. F. (2005). Durability design and performance of self-consolidating lightweight concrete. Construction and Building Materials, 19(8), 619-626.

Hwang, C.-L., Bui, L. A.-T., Lin, K.-L., \& Lo, C.-T. (2012). Manufacture and performance of lightweight aggregate from municipal solid waste incinerator fly ash and reservoir sediment for self-consolidating lightweight concrete. $\mathrm{Ce}$ ment \& Concrete Composites, 34(10), 1159-1166.

Hwang, S., Khayat, K., \& Bonneau, O. (2006). Performancebased specifications of self-consolidating concrete used in structural applications. ACI Materials Journal, 103(2), 121-129.

Karahan, O., Hossain, K. M. A., Ozbay, E., Lachemi, M., \& Sancak, E. (2012). Effect of metakaolin content on the properties self-consolidating lightweight concrete. Construction and Building Materials, 31(6), 320-325.

Khayat, K. H., Ghezal, A., \& Hadriche, M. S. (1998). Development of factorial design models for proportioning selfconsolidating concrete. In V. M. Malhotra (Ed.) Nagataki Symposium on Vision of Concrete: 21st Century (pp. 173-197). 
Khayat, K. H., Ghezal, A., \& Hadriche, M. S. (2000). Utility of statistical models in proportioning self-consolidating concrete. In Proceedings of the First International RILEM Symposium on Self-Compacting Concrete (pp. 345-359), Stockholm

Khayat, K. H., Lovric, D., Obla, K., \& Hill, R. (2002). Stability optimization and performance of self-consolidating concrete made with fly ash. In First North American Conference on the Design and Use of Self-consolidating Concrete (pp. 215-223). Chicago, IL: ACI. November 12-13

Kim, Y. J., Choi, Y. W., \& Lachemi, M. (2010). Characteristics of self-consolidating concrete using two types of lightweight coarse aggregates. Construction and Building Materials, 24(1), 11-16.

Lachemi, M., Bae, S., Hossain, K. M. A., \& Sahmaran, M. (2009). Steel-concrete bond strength of lightweight selfconsolidating concrete. Materials and Structures, 42(7), 1015-1023.

Müller, H. S., \& Haist, M. (2002). Self-compacting lightweight concrete-Technology and use. Concrete Plant Precast Technology, 71(2), 29-37.

Muthukumar, M., \& Mohan, D. (2004). Optimization of mechanical properties of polymer concrete and mix design recommendation based on design of experiments. Journal of Applied Polymer Science, 94(3), 1107-1116.

Nagataki, S., \& Fujiwara, H. (1995). Self-compacting property of highly flowable concrete. In V. M. Malhotra (Ed.) ACI SP (SP-154) (pp. 301-314). Farmington Hills, MI: American Concrete Institute.

Nehdi, M. L., \& Summer, J. (2002). Optimization of ternary cementitious mortar blends using factorial experimental plans. Materials Structure Journal, 35(8), 495-503.

Ozbay, E., Gesoglu, M., \& Guneyisi, E. (2011). Transport properties based multi-objective mix proportioning optimization of high performance concretes. Journal of Materials and Structures, 44(1), 139-154.

Patel, R., Hossain, K. M. A., Shehata, M., Bouzoubaâ, N., \& Lachemi, M. (2004). Development of statistical models for mixture design of high-volume fly ash self-consolidating concrete. ACI Materials Journal, 101(4), 294-302.

Pradeep, G. (2008). Response surface method. Saarbrücken: VDM Verlag Publishing. 76 p.

Schmidt, S. R., \& Launsby, R. G. (1994). In M. J. Kiemele (Ed.), Understanding industrial designed experiments (4th ed., pp. 1-48). Colorado Springs, CO: Air Academic Press.

Sonebi, M. (2004a). Medium strength self-compacting concrete containing fly ash: Modelling using factorial experimental plans. Cement and Concrete Research, 34(7), 1199-1208.

Sonebi, M. (2004b). Applications of statistical models in proportioning medium-strength self-consolidating concrete. ACI Materials Journal, 101(5), 339-346.

Sonebi, M., Bartos, P. J. M., Zhu, W., Gibbs, J., \& Tamimi, A. (2000). Final Report Task 4, Hardened Properties of SCC. Brite-EuRam, Contract No. BRPRTC96-0366, Hardened Properties of SCC (p. 75). Advanced Concrete Masonry Center, University of Paisley.

Sonebi, M., Grünewald, S., \& Walraven, J. (2007). Filling ability and passing ability of self-consolidating concrete. ACI Materials Journal, 104(2), 162-170.

Stamatakis, M. G., Bedelean, M., Gorea, H., Alfieris, D., Tziritis, E., \& Kavouri, S. (2011). Clay-rich rocks and mining wastes for the production of lightweight aggregates with thermal insulation properties. Refractories Worldforum, 3(1), 85-92.

Topçu, I. B., \& Uygunoğlu, T. (2010). Effect of aggregate type on properties of hardened self-consolidating lightweight concrete (SCLC). Construction and Building Materials, 24(7), 1286-1295.

Whitcomb, P. J., \& Anderson, M. J. (2004). RSM simplified: Optimizing processes using response surface methods for design of experiments (p. 292). New York, NY: Productivity Press.

Wu, Z., Zhang, Y., Zheng, J., \& Ding, Y. (2009). An experimental study on the workability of self-compacting lightweight concrete. Construction and Building Materials, 23(5), 2087-2092. 